\title{
Mistakes, Changed Circumstances and Intent
}

\author{
Nancy Kim*
}

\section{INTRODUCTION}

Suppose a purchaser wishes to buy a vacation home using the Internet. She desires a house in the country where she can escape the sounds and stresses of the city. On the basis of pictures posted on a website, she enters into an agreement to purchase a house that looks like an idyllic country home. During inspection, she discovers a noisy, nearby road. The house looks exactly as it does on the website, but the posted pictures failed to capture the surrounding environment. The purchaser imagined her mornings would be filled with the sounds of chirping birds, not blaring car horns. The noise from the road would not be unbearable to the average homebuyer, but it undermines the purchaser's reason for buying the house. Could our purchaser avoid the transaction? Should she be allowed to?

Contract law requires that in order for promises to be legally enforceable, they must be supported by consideration. ${ }^{1}$ A corollary, often referred to as the "bargain principle," provides that bargains will be

\footnotetext{
Associate Professor, California Western School of Law. B.A. 1987, University of California, Berkeley; J.D. 1990, Boalt Hall; LL.M. 1993, University of California, Los Angeles. I am thankful for the various comments that were received when the ideas in this paper were presented at the Western Law Professors of Color Conference, California Western School of Law, San Diego, Cal., March 31-April 2, 2006, the Conference of Asian Pacific American Law Professors, Wayne State University School of Law, Detroit, Mich., April 7-8, 2006 and the Annual Meeting of the Law and Society Association, Baltimore, Md., July 6-9, 2006. Special thanks to Tom Barton, Richard Carlson, Mike Dessent, and Neil Gotanda for their careful review of prior drafts and their helpful insights and suggestions, and to Helene Colin for her thorough research assistance. Thanks also to the editors of the Kansas Law Review, in particular Adam Gasper and Samia Khan, for their diligence and hard work. All errors are mine alone.

1. See lon L. Fuller \& Melvin Aron Eisenberg, Basic Contract LaW 8 (7th ed. 2001). While few scholars question that bargains supported by consideration are enforceable (absent available contract defenses, of course), many scholars dispute whether consideration is still a relevant or necessary requirement for enforcement of a promise. See id. at 8-9. In other words, while the existence of consideration may establish an enforceable promise, the absence of consideration should not necessarily preclude enforcement. For a discussion of the relevance of the "gatekeeping" function of consideration, see Mark B. Wessman, Should We Fire the Gatekeeper? An Examination of the Doctrine of Consideration, 48 U. MiAMI L. REV. 45 (1993).
} 
enforced according to their terms. ${ }^{2}$ Stated another way, as long as there is a bargained-for exchange of a legal detriment (or conferral of a legal benefit), courts should not consider the adequacy of consideration. There are, however, situations where the parties have entered into a bargain and then sought either to avoid enforcement or to reform the contract terms. A party seeking avoidance or reformation must prove one or more of several established "defenses" to enforcement. ${ }^{3}$ " The most common contract defenses are duress, unconscionability, incapacity, fraud, and the "basic assumption" defenses ${ }^{4}$ of mutual mistake, unilateral mistake, impossibility, frustration of purpose and commercial impracticability. ${ }^{5}$ In this Article, I limit my discussion to basic assumption defenses. Several prevailing rationales explain why a party should be allowed to escape contractual liability despite the sufficiency of consideration where there has been a failure of a basic assumption material to the transaction. No single rationale or principle, however, unifies all basic assumption defenses. Several commentators have noted that similar fact patterns applying a given doctrine often yield inconsistent results. ${ }^{6}$ Parties' employment of these defenses, and courts' analyses of them, is often confusing and inaccurate. ${ }^{7}$

2. See generally Melvin Aron Eisenberg, The Bargain Principle and Its Limits, 95 HARV. L. REV. 741 (1982). Eisenberg argues that in certain cases, such as those involving exploitation or unfair persuasion, limits on the bargain principle are justified. Id. at 748-86.

3. In this Article, I use the term "contract defenses" to refer to the ways that a party to an agreement can avoid its obligations despite the existence of mutual assent and valid consideration. Contract defenses are thus used to demonstrate that a particular bargain was a voidable contract. See RESTATEMENT (SECOND) OF CONTRACTS \& 7 (1981) (“A voidable contract is one where one or more parties have the power, by a manifestation of election to do so, to avoid the legal relations created by the contract, or by ratification of the contract to extinguish the power of avoidance.").

4. Basic assumption defenses are discussed in greater detail in Part III.

5. Nondisclosure is an issue that is relevant to certain defenses, such as mistake and fraud, but this Article does not treat it as a stand-alone defense.

6. See, e.g., James Gordley, Impossibility and Changed and Unforeseen Circumstances, 52 AM. J. COMP. L. 513, 513-14 (2004) ("[T]he attempt to explain which contracts should be enforced in terms of whether their performance is possible or not has been a failure."); Andrew Kull, Mistake, Frustration, and the Windfall Principle of Contract Remedies, 43 HASTINGS L.J. 1, 3 (1991) (observing that "judges and writers continue to defer to a supposed distinction between the doctrines [of mistake and frustration]" but that such a distinction is without a difference).

7. See discussion infra Part III. The variety of ways in which leading contract scholars have categorized contract defenses underscores the need for a unified framework. For example, Calamari and Perillo discuss infancy and mental infirmity in a chapter titled "Capacity of Parties," and duress, undue influence, misrepresentation, mistake and unconscionability in a chapter titled "Avoidance or Reformation for Misconduct or Mistake." Joseph M. Perillo, CAlamari AND Perillo on CONTRACTS vii (5th ed. 2003). Farnsworth discusses some defenses (such as infancy, insanity, duress, and unconscionability) in a chapter titled "Policing the Agreement," while the defenses of mistake, impracticability and frustration of purpose are discussed in the chapter "Failure of a Basic Assumption: Mistake, Impracticability, and Frustration." E. ALlAN FARNSWORTH, FARNSWORTH ON CONTRACTS xi-xv, xix (3d ed. 2004). Similarly, contract defenses are variously categorized in first year contracts casebooks. Fuller and Eisenberg, for example, categorize duress and 
This Article proposes that basic assumption defenses can best be explained and analyzed through the prism of contractual intent. Although typically discussed in terms of a singular concept, contractual intent in fact comprises various facets, which I refer to as volitional intent, cognitive intent, and contextual purposive intent. Part II provides an introduction to, and description of, my proposed expanded intent analysis. Part III applies expanded intent analysis to cases involving basic assumption defenses. Part IV addresses possible concerns with using a dynamic approach/expanded intent analysis. This Article concludes that adopting my proposed intent-based analysis has several advantages over the current application of contract defenses. First and foremost, it directly addresses and incorporates contract law's two primary objectives: furthering autonomy and facilitating transactions. Second, because it removes artificial doctrinal distinctions, it eliminates or minimizes confusion and simplifies analysis. Consequently, it provides for greater consistency in judicial decisions. Finally, the approach is flexible, and therefore better accommodates technological advancements, such as the Internet, in the modern marketplace.

\section{THE THREE FACETS OF CONTRACTUAL INTENT}

Various rationales justify each basic assumption defense, yet there is no one consistent organizing principle or framework by which to analyze all of them. ${ }^{8}$ Because each defense incorporates both contract-based and

unconscionability in the chapter titled "The Bargain Principle and Its Limits," while mistakes and impracticability are discussed in a chapter titled "Mistakes and Changed Circumstances." FULLER \& EISENBERG, supra note 1, at v-vi. MacNeil and Gudel include misrepresentation, duress, undue influence, capacity, and unconscionability in a chapter titled "Social Control and Utilization of Contractual Relations," but mistakes are included in the chapter "Consequences of Incomplete and Ineffective Risk Planning." IAN R. MACNeIL \& PAUL J. GudEL, CONTRACTS ExCHANGE TRANSACTIONS AND RELATIONS xxi, xxix (3d ed. 2003) (organizing basic assumption defenses, as this Article does, by separating those based on unanticipated events that occur before contract formation from those that occur after contract formation).

Not surprisingly, teaching and learning contract defenses is often challenging. One law professor describes teaching contract defenses as "one of the more difficult parts of the basic contracts course" and describes them as "tricky" for students to learn. Miriam Cherry, $A$ Tyrannosaurus-Rex Aptly Named "Sue": Using a Disputed Dinosaur to Teach Contract Defenses, 81 N.D. L. REV. 295, 297-99 (2005).

8. See Richard A. Posner \& Andrew M. Rosenfield, Impossibility and Related Doctrines in Contract Law: An Economic Analysis, 6 J. LEGAL STUD. 83, 84 (1977) (noting "an inability to develop a coherent positive theory consistent with the typical outcomes" in recurring cases dealing with impossibility, frustration of purpose and impracticability). See also Kull, supra note 6, at 2-3 (noting that "mistake" and "frustration" are "logically and functionally indistinguishable" and describing them as "two names for the same problem"). Andrew Kull promotes the "windfall principle" as a unified conceptual model to explain mistake and frustration cases. Under this theory, "[d]isparities between anticipation and realization ... the risk of which [have] not been allocated by 
policy-oriented justifications unique to that defense, each defense typically must be examined on its own terms rather than as part of a larger theory or principle that unifies all defenses. A dynamic approach to contract defenses would essentially eliminate the need for the existing doctrinal categories and, along with it, much of the concomitant confusion surrounding their application. I propose a dynamic approach that first examines the intent of the contracting parties, and then weighs the parties' intent against society's interests in the security of transactions. ${ }^{9}$ Discussions of free will have tended to overshadow intent as a subject of scholarly inquiry. ${ }^{10}$ If contracts are enforceable because they are the expressions of the free will of the parties, then contracts that are not freely entered into should not be enforced. While this rationale may explain the defense of duress, it does not precisely or adequately capture basic assumption defenses. For example, one entering into a contract based upon a mistake is not being deprived of free will. The notion of "free will" or volition is but one aspect of intent. Intent is often equated with contractual purpose and conscious deliberation. Yet, in many cases a failure to consider an occurrence (i.e., a lack of conscious deliberation) undermines contractual purpose.

Intent is not a monolithic or neutral concept. Determinations of intent hinge upon a party's credibility. ${ }^{11}$ Whether a party is found to be credible often depends upon whether the fact-finder understands or relates to that party. In some cases, however, the party and the fact-

the parties, are ... windfalls ...." Id. at 6 .

9. As Mel Eisenberg notes:

A modern free enterprise system depends heavily on exchanges over time and on private planning. The extent to which actors will be ready to engage in such exchanges, and are able to make reliable plans, depends partly on the probability that promises to render a bargained-for performance will be kept.

Eisenberg, supra note 2, at 744

10. As one commentator noted:

[T] here continues to be a significant amount of debate among contract law scholars over the criteria necessary to determine whether a choice was freely made. While legal scholars are in agreement that man possesses free will and that free will is necessary to form an enforceable contract, they do not agree on criteria to determine whether the will is free in a particular situation.

Philip Bridwell, Comment, The Philosophical Dimension of the Doctrine of Unconscionability, 70 U. CHI. L. REV. 1513, 1517 (2003).

11. According to Randy E. Barnett:

[W] never have direct access to another individual's subjective mental state. We thus must always learn the meaning of terms by comparing (1) the conduct of persons with their words, or (2) their conduct and words in one context with those in another, or (3) one person's conduct and words with another person's conduct and words. Even in a subjective theory, evidence of subjective assent must be manifested at some point - if only from the witness stand or in self-serving documents.

Randy E. Barnett, A Consent Theory of Contract, 86 COLUM. L. REv. 269, 305 (1986). 
finder may not share the same set of social or cultural assumptions or understandings, and the same act may have different meanings depending upon the actor. Thus, the likelihood of misunderstandings arises where cultural dissonance ${ }^{12}$ exists between the fact-finder and a party to a contract dispute. Ilhyung Lee, for example, has examined the differing role of the apology in Korean, Japanese, and American societies, and emphasized the importance of recognizing such differences in dispute resolution. ${ }^{13}$ A recent article in the Harvard Business Review explained how communication in Western cultures is direct and explicit, whereas in many other cultures, meaning is embedded in the way the message is presented. ${ }^{14}$ The authors of that article noted that the differences between indirect and direct communication can profoundly affect cross-cultural business relationships. ${ }^{15}$ In addition to direct versus indirect communication, they discussed three other categories of crosscultural tension within multicultural teams: trouble with accents and fluency, differing attitudes toward hierarchy and authority, and conflicting norms for decision-making. ${ }^{16}$ They also observed significant cultural differences in decision-making, particularly in "how quickly decisions should be made." 17

The purpose of contract law is often said to be the "realization of reasonable expectations induced by promises." 18 Reasonable expectations, however, do not provide the guiding philosophy or theoretical underpinning for contract law. It explains what contract law tries to accomplish, but not why. Two primary philosophical justifications explain why contract law exists. The first is that private

12. Elsewhere, I have defined "cultural dissonance" as differing socio-cultural and experiential backgrounds. See Nancy S. Kim, Blameworthiness, Intent and Cultural Dissonance: The Unequal Treatment of Cultural Defense Defendants, 17 FLA. J.L. \& PUB. POL'Y 199, 202 (2006).

13. Ilhyung Lee, The Law and Culture of the Apology in Korean Dispute Settlement, 27 Mich. J. INT'L L. 1, 1-7 (2005).

14. See Jeanne Brett, Kristin Behfar \& Mary C. Kern, Managing Multicultural Teams, HARV. Bus. ReV., Nov. 2006 at 84.

15. In one situation, an American project manager working with Japanese team members explained:

In Japan, they want to talk and discuss. Then we take a break and they talk within the organization. They want to make sure that there's harmony in the rest of the organization. One of the hardest lessons for me was when I thought they were saying yes but they just meant "I'm listening to you." Id. at 86 .

16. Id. Brett, Behfar and Kern conclude that cultural challenges to management are manageable provided that management avoids imposing single-culture-based approaches on multicultural situations. $I d$.

17. Id. at 88 .

18. ARTHUR LinTON CORBIN, CORBIN ON CONTRACTS $§ 1$ (1952). 
agreements should be enforced because contracting promotes individual autonomy. ${ }^{19}$ The second predominant justification for contract law is that it encourages market transactions and is beneficial to a credit economy. ${ }^{20}$ Neither justification alone suffices. If the objective of contract law is simply to promote individual autonomy, then no contract should be enforced unless there was a subjective intent on the part of each of the parties to enter into that contract. If, however, the sole objective of contract law is to encourage promissory exchanges, then the courts should only permit a party to avoid its contractual obligations where there was little or no economic or social utility to that contract. Contract defenses navigate the waters between these two philosophies, and thus capture the dynamic nature of neoclassical contract law. ${ }^{21}$

Dynamic or "neoclassical" contract law $^{22}$ considers not only the individualistic objectives of contract, but policy issues as well. ${ }^{23}$ Dynamic contract law $^{24}$ adopts as its initial point of inquiry the

19. See generally Charles Fried, Contract as Promise: A Theory of Contractual OBLIGATION (1981); Barnett, supra note 11.

20. See generally A. Mitchell POLINSKy, AN INTRODUCTION TO LAW AND ECONOMics (2d ed. 1989); Lewis A. Kornhauser, An Introduction to the Economic Analysis of Contract Remedies, 57 U. COLO. L. REV. 683 (1986); Richard Craswell, Two Economic Theories of Enforcing Promises, in The Theory of Contract Law, New Essays (Peter Benson ed., 2001); Richard A. Posner, THE PROBLEMS OF JURISPRUDENCE (1990).

21. Not surprisingly, much of what shall be discussed with respect to "basic assumption" defenses in this Article is applicable to other contract defenses, such as fraud and duress.

22. Neoclassical contract law is associated with Corbin and the Restatement (Second) of Contracts, and Llewellyn and the Uniform Commercial Code. John E. Murray, Jr., Contract Theories and the Rise of Neoformalism, 71 FORDHAM L. REV. 869, 870 (2002).

23. The concept of dynamic modern contract law was first discussed by Melvin Eisenberg in an essay. See generally Melvin Aron Eisenberg, The Emergence of Dynamic Contract Law, 88 CAL. L. REV. 1743 (2000). For further general discussion, see Nancy Kim, Evolving Business and Social Norms and Interpretation Rules: The Need for a Dynamic Approach to Contract Disputes, 84 NEB. L. REV. 506 (2005). Karl N. Llewellyn is the scholar most closely associated with a dynamic approach to contracts. Murray, supra note 22, at 891 ("Llewellyn insisted that the 'text' of the bargain should no longer be the sole basis for discerning obligations. Rather, 'dynamic, legally unformulated, fact patterns of common life' provide an 'immanent law' from which the parties' obligations are derived." (citing Omri Ben-Shahar, The Tentative Case Against Flexibility in Commercial Law, 66 U. CHI. L. REV. 781, 782 (1999)). See also Jay M. Feinman, The Significance of Contract Theory, 58 U. CIN. L. REV. 1283, 1288-1289 (1990).

24. Neoclassical contract law, however, is not interchangeable with "modern" contract law, as evidenced by the rise in "neoformalism." See generally Murray, supra note 22. Murray identifies neoformalism as the reaction to the dynamic character of neoclassical law. Id. at 891 . Neoformalists are those who

would create a world of "plain meaning" interpretation, ridding the adjudication of contract disputes of any evidence unexpressed in words, reinstating a draconian parol evidence rule, and even precluding the parties themselves from modifying their contract or waiving one or more terms in any fashion other than express terms.

Id. at 912. In other words, neoformalism is the antithesis of dynamic contract law.

I distinguish dynamic contract law from neoclassical contract law to emphasize that while 
subjective intent of the parties. ${ }^{25}$ The existence (or non-existence) of a party's subjective intent, however, must then be balanced by public policy concerns, which reflect societal interests. ${ }^{26}$ In the case of basic assumption defenses, the primary policy concern is society's interest in the security of economic transactions.

While promulgating the "intent of the parties" is generally agreed to be one of the primary objectives of contract law, the larger issues of determining what that intent is and how to effectuate it have not been resolved. Traditionally, the discussion concerning contractual intent has revolved around the Williston versus Corbin debate regarding whether contract interpretation should be objective, or objective with "subjective elements." This debate, however, misses the point because it reflects, rather than resolves, the fundamental tension in contract law between the interests of the individual and the interests of society.

In this section, I set forth a three-part expanded analysis of intent. Generally, when a party to a contract seeks to avoid enforcement, she in essence is claiming that she did not intend to enter into the agreement at all (but was forced), or did not intend to enter into this agreement (but was misled, circumstances changed, etc.). ${ }^{27}$ Consequently, such a contract should be enforced only if there is a strong countervailing societal interest supporting enforcement.

neoclassical contract law tends to adopt a more dynamic approach, it is not yet entirely "dynamic" in nature and retains remnants of its classical contract past (such as the requirement of consideration).

25. While dynamic contract law examines subjective intent, it is rarely "actual" intent simply because in many cases actual intent is non-existent. If the parties had actually considered the issue giving rise to the request for avoidance, they would have addressed it. Many scholars object to a purely subjective standard. For example, Randy Barnett observes:

objectively manifested consent, which usually reflects subjective intent, provides a far sounder basis for contractual obligation than do subjectively held intentions. Evidence of subjective intent that is extrinsic to the transaction and was unavailable to the other party is relevant, if at all, only insofar as it helps a court to ascertain the "objective" meaning of certain terms

Barnett, supra note 11, at 304. Yet, the problem with objectively manifested consent is that it assumes the parties share the same socio-cultural reference points, an assumption that many anthropologists and linguists dispute. See generally ROLAND BARTHES, MYTHOLOGIES (Annette Lavers, 1972); FERDINAND DE SAUSSURE, COURSE IN GENERAL Linguistics (Charles Balley \& Albert Sechehaye eds., 1972).

26. Eisenberg, supra note 23 , at 1745

27. Andrew Kull notes:

Though a promise is expressed in unqualified terms, a person does not normally mean to bind himself to do the impossible, or to persevere when performance proves to be materially different from what both parties anticipated at the time of formation. Faced with the adverse consequences of such a disparity, even a person who has previously regarded his promise as unconditional is likely to protest that he never promised to do that.

Kull, supra note 6, at 38-39. 


\section{A. Volitional Intent}

Contractual assent requires what I refer to as "volitional intent." Volitional in this regard is more than an absence of physical coercion; it means willingness to enter into the contract. ${ }^{28}$ This type of willingness assumes both a mental and emotional voluntariness as well as an unimpaired state of mind on the part of the parties. A failure of volitional intent is thus found in cases that currently raise the defenses of intoxication, insanity, duress, ${ }^{29}$ and procedural unconscionability. ${ }^{30}$ Could the party seeking avoidance control her actions? Was the avoiding party coerced into signing the agreement? Volitional intent assumes the autonomous nature of the avoiding party's conduct. In other words, was the act of contracting desired? Consequently, the nonavoiding party's conduct is relevant, but only to the extent that it affects the avoiding party's autonomy. Basic assumption defenses do not usually involve an absence of volitional intent. ${ }^{31}$ Accordingly, the remainder of this Article will focus primarily on the cognitive and contextual purposive aspects of intent.

\section{B. Cognitive Intent}

A fundamental component of intent is that the contracting parties understood what they were doing. In other words, not only should the parties act voluntarily when they enter into an agreement, but they should know what it is that they are voluntarily agreeing to do. An inquiry into

28. In so doing, I adopt the typical dictionary definition of "volition." Webster's, for example, defines volition as follows: "1. An act of willing, choosing, or deciding. 2. A conscious choice : DECISION. 3. Power or capability of choosing : WILL." WeBSTER's II NEW COLLEGE DICTIONARY 1238 (1995). A larger issue is the distinction that should be made between a volitional intent to enter into the transaction and the volitional intent to enter into the written contract. This is a distinction that arises most often with form agreements, including click-wrap and shrink-wrap agreements. See generally Nancy Kim, Clicking and Cringing, 86 OR. L. REV. 797 (2007).

29. These defenses may also acknowledge an absence of one or more of the other types of intent as well.

30. A lack of volitional intent would be found with respect to procedural, as opposed to substantive, unconscionability. Arthur A. Leff, Unconscionability and the Code-The Emperor's New Clause, 115 U. PA. L. REV. 485, 489-90 (1967). In many cases, however, the distinction between "procedural" and "substantive" unconscionability become blurred, particularly since substantively unfair terms are often the result of bargaining naughtiness.

31. There may, however, be cases that involve basic assumption defenses as well as defenses where there is an absence of volitional intent. More specifically, the same fact pattern may involve both a basic assumption defense such as mistake, and a defense evidencing an absence of volitional intent, such as duress. In that case, however, the duress claim would indicate the lack of volitional intent, not the mistake claim. 
cognitive intent ${ }^{32}$ asks what information the avoiding party had when he or she entered into the contract. Was the avoiding party operating under a belief about a material fact that was wrong (i.e., a mistaken "basic assumption")? Was the avoiding party tricked or misled by the other party? Had the avoiding party considered the possibility of the occurrence of the excusing event (i.e., was there conscious ignorance or a conscious allocation of risk)? In every contracting situation, each party has limited knowledge and is usually aware of its limited knowledge. ${ }^{33}$ The cognitive facet of intent, however, does not refer to what a party actually knows (or does not know). Cognitive intent takes into account what the parties considered at the time the contract was made. It captures any conscious and express risk allocation between the parties, although it does not consider default risk allocation. ${ }^{34}$ It does not require that the parties expressly address the excusing condition in the written agreement. On the other hand, it does not require that the excusing condition be unforeseeable. Judicial recognition of cognitive intent is most evident in cases that raise the contract defenses of fraud, mistake and unconscionability. Cognitive intent also captures the rationale underlying some cases involving the defenses of intoxication and immaturity.

\section{Contextual Purposive Intent}

In order to determine whether a party in fact intended to enter into a contract, it is necessary to examine both why the party entered into the contract, and the relevant circumstances. ${ }^{35}$ In other words, contextual purposive intent examines a party's motive in entering into the contract. ${ }^{36}$ The relevant circumstances include both those existing at the time the contract was made as well as those arising after contract formation. ${ }^{37}$

32. DiMatteo describes a "second-order intent" that would "imbu[e] the reasonable person with the knowledge of what the parties knew and what they should have known." Larry A. DiMatteo, The Counterpoise of Contracts: The Reasonable Person Standard and the Subjectivity of Judgment, 48 S.C. L. REV. 293, 318 (1997). Cognitive intent reflects aspects of DiMatteo's second-order intent, but differs from it in that it focuses on the subjective intent of the party.

33. Kull, supra note 6, at 2 .

34. See discussion infra Part III.B.

35. Contextual purposive intent is captured in Karl Llewellyn's vision of a "contextual agreement." See John E. Murray, Jr., The Article 2 Prism: The Underlying Philosophy of Article 2 of the Uniform Commercial Code, 21 WASHBURN L.J. 1, 1-8 (1981) (discussing Llewellyn's views).

36. For a discussion of when a "mistake in motive" should provide relief, see James Gordley, Mistake in Contract Formation, 52 AM. J. CoMP. L. 433 (2004). Gordley believes that in most cases, errors in motive should not warrant relief, but that in certain cases, they do, and should. Id. at $435,461-68$.

37. The importance of examining contractual relations at moments other than at the time of 
Contextual purposive intent acknowledges concepts of fairness and substantive justice that are hidden in many of the defense doctrines. It requires - in fact, assumes - that the avoiding party acted honestly with respect to her conduct and intention in entering into the agreement. ${ }^{38}$ For example, a promisor who lied to a promisee could not escape contractual liability by claiming that his contextual purposive intent, or motive, in entering into the contract was not to perform, but was instead to mislead the promisee into undertaking some action. ${ }^{39}$ The promisee, on the other hand, would be able to avoid contract enforcement. This requirement of good faith corresponds to the ordinary dictionary definition of the term. ${ }^{40}$ To the extent, however, that good faith implies a norm, such as "commercial reasonableness," 41 that standard does not apply with respect to the determination of intent. ${ }^{42}$

contract formation has been noted by other scholars. For example, Barnhizer has noted:

$[\mathrm{T}]$ he relative bargaining power of the parties can shift throughout their interaction. But courts have no consistent approach to the point at which they will assess inequality of bargaining power. Some courts, for example, analyze relative bargaining power at the time of the initial offer. Others look to the bargaining power existing at the time of contracting or even at the eventual outcome of the parties' bargain. Given the dynamic nature of the power relationship on the level of individual contracts, the choice of timing for analysis will significantly affect that analysis.

Daniel D. Barnhizer, Inequality of Bargaining Power, 76 U. CoLO. L. REV. 139, 232-33 (2005).

38. For a discussion of the role of intent in promissory fraud cases, see generally IAN AYRES \& Gregory Klass, Insincere Promises: The LAW of MisRePresented InTENT (2005). The authors of that book analyze the intent of the promisor in situations where the innocent promisee seeks either to enforce the misrepresentation or sue for reliance based upon the false promise. $I d$. at 16-17. My analysis, on the other hand, considers the intent of the promisor in cases where the promisor wishes to avoid contract enforcement. A promisor who never intended to fulfill her promise would not be allowed to escape her contractual obligations on the basis of lack of intent due to the lack of good faith.

39. This would be an example of promissory fraud. See generally AYRES \& KLASS, supra note 38.

40. The Oxford Dictionary defines "good faith" as "honesty or sincerity of intention." OXFORD DiCTIONARY 585 (9th ed. 1995). Although good faith means honesty, mere negligence does not amount to bad faith. In other words, a party who acts honestly but negligently may still be acting in good faith. See also Restatement (SECOND) OF CONTRACTS $\S 157 \mathrm{cmt}$. a (1981) ("The mere fact that a mistaken party could have avoided the mistake by the exercise of reasonable care does not preclude ... avoidance [on the basis of mistake]"). Ayres and Klass discuss the role of motive, but primarily with respect to determining whether the promisor intended to defraud or mislead the promisee. AYRES \& KLASS, supra note 38, at 135-40.

41. The U.C.C., for example, has interpreted good faith to mean "honesty in fact and the observance of reasonable ... standards of fair dealing in the trade." U.C.C. § 2-103 (1998). The Restatement provides that "[e]very contract imposes upon each party a duty of good faith and fair dealing in its performance and its enforcement." RESTATEMENT (SECOND) OF CONTRACTS $§ 205$ (1981). For a critical evaluation of the way courts currently employ the doctrine of good faith, see Emily M.S. Houh, The Doctrine of Good Faith in Contract Law: A (Nearly) Empty Vessel?, 2005 UTAH L. REV. 1 (2005).

42. That standard is, however, relevant to the second part of a dynamic analysis, which concerns whether avoiding the contract will undermine the security of transactions. Trade norms may be relevant, however, in determining the veracity of a party's claimed cognition or contextual 
Contextual purposive intent is currently reflected primarily in successful cases raising the defense of unconscionability, ${ }^{43}$ undue influence, frustration of purpose, and commercial impracticability. Again, the rationale underlying any of these contract defenses may include a lack of the other facets of intent discussed above. Most changed circumstances contract defenses, for example, indicate a lack of both cognitive intent (because of the failure to consider and accurately predict the future) and contextual purposive intent. Facts indicating a lack of contextual purposive intent do not necessarily also indicate a lack of cognitive intent. For example, a grieving widower who signs his property over to his deceased beloved wife's family may not lack cognitive intent, but may lack contextual purposive intent. His purpose in entering into the agreement is not to convey his property, but to demonstrate his gratitude and affection to his wife's memory. ${ }^{44}$ Thus, in some cases, contextual purposive intent may capture the function that consideration had under classical contract law.

Both cognitive and contextual purposive intent involve certain "tacit assumptions" $^{\text {"45 }}$ about the proposed agreement. A party's rationale for entering into an agreement may be undermined where a party's tacit assumptions prove to be invalid. In such a case, it may no longer be accurate to say that the party intended to enter into the agreement given the circumstances as they actually were or turned out to be. Thus, consideration of cognitive, and especially contextual purposive, intent requires disregarding the parol evidence and plain meaning rules. Although this sounds radical in concept, as Part III illustrates, many courts already construe both rules so as to minimize or undermine their impact. $^{46}$

purposive intent.

43. Contextual purposive intent will tend to demonstrate "substantive" unconscionability. See Leff, supra note 30, at 509 (discussing the drafting history of substantive unconscionablility).

44. I thank H.G. Prince for sharing this example with me.

45. FULLER \& EISENBERG, supra note 1, at 743. Fuller and Eisenberg note that "[w]ords like 'intention' ... imply a conscious state involving an awareness of alternatives and a deliberate choice among them. It is, however, plain that there is a psychological state that can be described as a 'tacit assumption,' which does not involve a consciousness of alternatives." Id. at 744 (emphasis omitted).

46. See Eyal Zamir, The Inverted Hierarchy of Contract Interpretation and Supplementation, 97 COLUM. L. REV. 1710, 1729-30 (1997) (discussing how many courts cite the plain meaning rule yet fail to adhere to it); Harry G. Prince, Contract Interpretation in California: Plain Meaning, Parol Evidence, and Use of the "Just Result" Principle, 31 LOY. L.A. L. REV. 557, 570 (1998) (noting that California courts tend to engage in a contextual analysis despite citing the plain meaning rule). See Eric A. Posner, The Parol Evidence Rule, the Plain Meaning Rule, and the Principles of Contractual Interpretation, 146 U. PA. L. REV. 533, 534 (1998) (discussing how courts may adopt a "hard" or "soft" version of the parol evidence rule). 
If the furtherance of individual autonomy were the only rationale underlying contract enforcement, one might argue that only subjective intent should be relevant, and that a party should always be able to escape contractual liability in the event that the party misunderstood the terms of an agreement or simply changed her mind. Yet, a completely subjective standard would decrease the reliability of agreements, and would consequently impede the flow of transactions. Thus, consideration of the party's subjective intent must be tempered by the other objective of contract law-to encourage promissory transactions by ensuring the security of transactions. Classical contract law strove to reconcile these two competing objectives by analyzing the disputed exchange from the standpoint of a "reasonable man." Although created in order to accommodate the twin goals of contract law, "reasonableness" supplants them. ${ }^{48}$ It collapses the two primary objectives of contract law into one standard. Modern contract law also adopts the objective theory, albeit with "subjective elements." A tension arises in contract law between the objective theory's goal of norm creation and reinforcement, and the subjective theory's deference to individuals' desires. This tension manifests itself in the law's approach to contract defenses. I propose an alternative approach that balances the three facets of intent against society's interest in the security of transactions, which, in turn, promotes market exchanges in a credit economy. The following diagram illustrates this approach:

47. Feinman, supra note 23 , at $1285-89$.

48. As my colleague Tom Barton pointed out, the objective standard may actually undermine both of contract law's objectives by ignoring individual autonomy in a given case, and because a "reasonable person" may, due to bounded rationality, engage in economically inefficient transactions. 
Dynamic Approach to Contracts

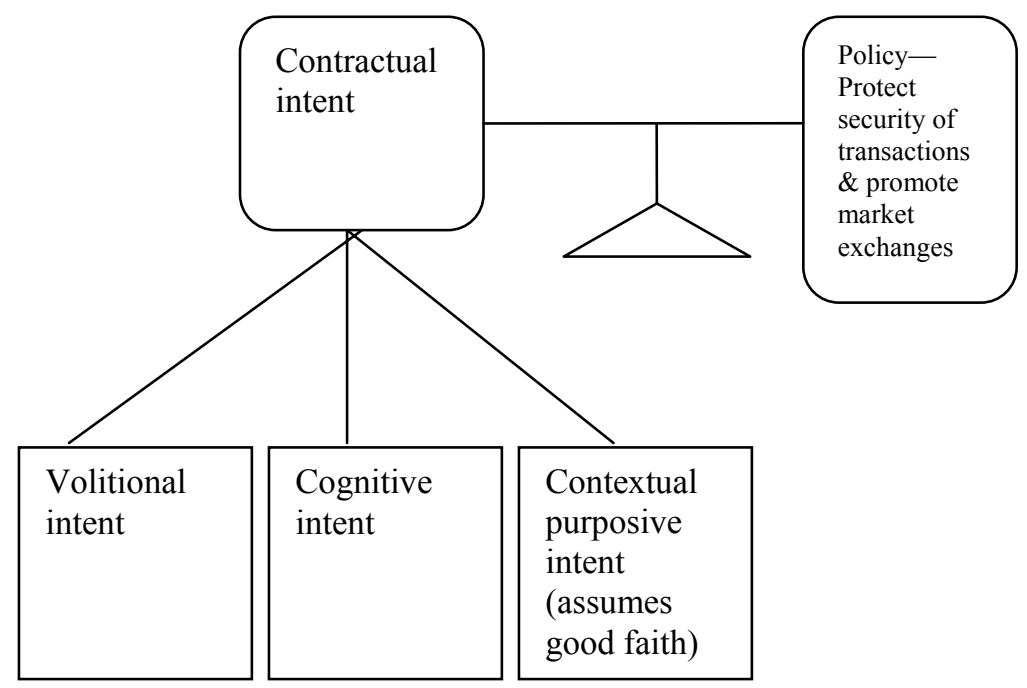

Volitional intent analysis asks whether the party wanted to enter into the transaction. Cognitive intent analysis asks whether the party understood what she or he was doing. Contextual purposive intent analysis considers the party's reason or motive for entering into the transaction. In the following section, I examine each of the basic assumption defenses in the context of a given case, and then analyze the case through the prism of the aforementioned expanded intent analysis.

\section{APPLYING THE INTENT ANALYSIS to BASIC ASSUMPTION DEFENSES}

Basic assumption defenses can be divided into two categories - those based upon facts existing at the time of contract formation, and those based upon facts arising after contract formation. The distinction between the two is a legacy of classical contract law's fixation on formation, and unnecessarily complicates analysis of problems arising from basic assumption errors. As this Section explains, the critical issue is not the timing of events, but the parties' contractual intent. 


\section{A. Pre-Formation Basic Assumption Errors}

\section{Mutual Mistake}

As many first-year Contracts professors know, ${ }^{49}$ the doctrine of mistake continues to baffle many students who are unable to reconcile the different outcomes in similar cases. ${ }^{50}$ The cases where an adversely affected party has been allowed to avoid a contract on the grounds of mutual mistake are inconsistent in both reasoning and result. ${ }^{51}$ In one familiar case, Wood v. Boynton, the plaintiff sold what she believed to be a rock to the defendant, who was also unaware of its identity. ${ }^{52}$ When the plaintiff discovered that the rock was in fact an uncut diamond, she sought to rescind the sale by offering the original price plus interest. ${ }^{53}$ The buyer refused and the seller sued. ${ }^{54}$ The court found that the seller had assumed the risk that the stone would be of greater value than the price the buyer paid. ${ }^{55}$

Sherwood v. Walker ${ }^{56}$ stands in stark contrast. In that case, the parties entered into an agreement for the sale of a cow. ${ }^{57}$ Both parties believed that the cow was barren. ${ }^{58}$ When the cow was discovered to be

49. See generally Cherry, supra note 7.

50. See also FARNSWORTH, supra note 7, § 9.3 ("The cases in which an adversely affected party has been allowed to avoid the contract on [the ground of mutual mistake] are not marked by their consistency in either reasoning or result.").

51. Id. See also Melvin A. Eisenberg, Mistake in Contract Law, 91 CAL. L. REv. 1573, 1575 (2003). Eisenberg states:

The problems raised by mistake have been a source of persistent difficulty in contract

law. In part this difficulty results from the complex nature of the underlying issues....

Much of the difficulty, however, results from the use of legal categories and doctrinal rules that are not sufficiently based on a functional analysis. Id. at 1575 .

Eisenberg proposes a functional analysis of issues raised by mistake which involves characterizing the type of mistake, and then developing the rules that should govern each type of mistake in light of applicable social propositions. Id. at 1576-78.

52. 25 N.W. 42, 44 (Wis. 1885). I am somewhat skeptical that the buyer, who was a jeweler, did not know that the "rock" was actually a diamond, but am of course constrained by the court's factual findings in the case.

53. Id. at 43 .

54. Id.

55. See id. at 45 ("[I]n the absence of fraud or warranty, the value of the property sold, as compared with the price paid, is no ground for rescission of sale.").

56. 33 N.W. 919 (Mich. 1887).

57. Id. at 919 .

58. Id. at 920 . The dissent points out, however, that the buyer might not have been entirely convinced of the infertility of the cow Rose of Abermarle:

The record ... shows that the defendants, when they sold the cow, believed the cow was not with calf, and barren; that from what the plaintiff had been told by defendants (for it 
with calf, the defendants sought to rescind the agreement by withholding delivery. ${ }^{59}$ The court found in favor of the defendants, stating that the mistake of the parties "was not of the mere quality of the animal, but went to the very nature of the thing. A barren cow is a substantially different creature than a breeding one." 60

Under expanded intent analysis, the parties in both cases, while possessing volitional intent, lacked the cognitive intent to enter into the contract. In Sherwood v. Walker, the parties believed they were contracting for an infertile cow, but their information was inaccurate. ${ }^{61}$ The parties never intended to enter into a contract for the sale and purchase of a fertile cow - at least not for the price that was paid. ${ }^{62}$ In Wood v. Boynton, the parties similarly did not intend to enter into a contract for the purchase and sale of an uncut diamond. ${ }^{63}$ In addition, the sellers in both cases lacked the contextual purposive intent to enter into the contract given the facts as they actually were. The seller in Wood $v$. Boynton intended to sell a rock, not a diamond. ${ }^{64}$ The seller in Sherwood $v$. Walker intended to sell a barren cow, not a fertile one. ${ }^{65}$ The seller in each case might have sold the item in question at a higher price if its true nature were known, but they might just as well not have wanted to sell the item at all. For example, the seller in Sherwood v. Walker might have decided to keep the cow to produce calves. The seller in Wood $v$. Boynton might have preferred to keep the diamond for herself. The buyers, on the other hand, lacked cognitive intent, but not contextual purposive intent. They did not know what they were buying, and so they could not have had the cognitive intent to engage in the transaction. Their contextual purposive intent in entering into the transaction was to

does not appear he had any knowledge or facts from which he could form an opinion) he believed the cow was farrow, but still thought she could be made to breed .... There is no question but that the defendants sold the cow representing her of the breed and quality they believed the cow to be, and that the purchaser so understood it. And the buyer purchased her believing her to be of the breed represented by the sellers, and possessing all the qualities stated, and even more. He believed she would breed. There is no pretense that the plaintiff bought the cow for beef, and there is nothing in the record indicating that he would have bought her at all only that he thought she might be made to breed.

Id. at 924-25 (Sherwood, J., dissenting).

59. Id. at 923 .

60. Id.

61. Id.

62. Id

63. Even if the buyer did intend to buy an uncut diamond, it is clear that the seller did not intend to sell one. The intent analysis looks at whether both parties intended to enter into the agreement.

64. 25 N.W. 42, 43-44 (Wis. 1885).

65. Sherwood, 33 N.W. at 923. 
promote their pecuniary interest - something that was not defeated, but rather promoted when the true facts were discovered. The buyer in Sherwood v. Walker, for example, intended to buy a cow for financial reasons (to sell its milk or meat), not for emotional ones (to keep as a pet). ${ }^{66}$ The jeweler/buyer in Wood v. Boynton presumably intended to buy a rock to sell to his customers (i.e. to make money) and not because he was a rock collector. Neither buyer's purpose in entering into the contract was injured or undermined by his discovery. ${ }^{67}$

Under a dynamic approach, however, the intent inquiry would not end the analysis of enforceability. A court might still choose to enforce the contract if society's interest in the security of transactions outweighed the lack of intent. In Sherwood v. Walker, the plaintiffs sought to enforce the contract by claiming title had passed, whereas the defendants retained possession of the cow and claimed the contract was executory. ${ }^{68}$ By contrast, in Wood v. Boynton, the plaintiff seller sought rescission after the money was paid and possession of the diamond transferred to the defendant buyer. ${ }^{69}$ It may be that the societal interest in ensuring the stability of transactions is undermined to a greater extent where the agreement has been fully performed (e.g., where property has already been paid for and delivered). ${ }^{70}$

The Second Restatement attempts to capture the doctrine of mistake. It defines mistake as "a belief that is not in accord with the facts." "71 In order to avoid a contract based on mistake, the mistake must be one as to a "basic assumption on which the contract was made," "material effect on the agreed exchange of performances." requirement that the mistake have a "material effect" reflects both the relevance of intent, and the promotion of a policy of fairness. The intent aspect considers whether the parties would have entered into the contract if they had known the facts as they actually were. In addition, the "material effect" requirement promotes fairness, and thus, contractual

\footnotetext{
66. Id.

67. I provide this discussion to demonstrate the differences between cognitive and contextual purposive intent. The fortunate buyer in a mistake situation is not injured and would not be trying to avoid enforcement of the contract; thus, her intent would not be at issue.

68. Sherwood, 33 N.W. at 919.

69. Wood, 25 N.W. at 44

70. Andrew Kull has noted the judicial disposition to let "windfalls lie," meaning that courts will not enforce executory agreements based upon a mistake, but neither will they rescind fully performed agreements despite the existence of a mutual mistake. See generally, Kull, supra note 6,

71. RESTATEMENT (SECOND) OF CONTRACTS $§ 151$ (1981).

72. Id. $\S 152$.

73. Id.
} at 6 . 
exchanges. Prospective parties are more likely to engage in contracts if judicial enforcement in mistake situations is perceived as fair.

A further requirement is that the mistake must relate to facts existing at the time the contract was made. ${ }^{74}$ If these requirements are met, the contract is voidable by the adversely affected party provided that he or she did not "bear[] the risk of the mistake.", A requirement that the avoiding party not bear the risk of the mistake furthers the fairness objective.

The remedies for mutual mistakes are avoidance and restitution. ${ }^{76}$ In fashioning a remedy, however, the courts often reveal their confusion of "mutual mistakes" with transcription errors or "mistakes in transcription." 77 Thus, courts have ordered reformation ${ }^{78}$ after finding the existence of a "mutual mistake." For example, in Shupe v. Nelson, a California appellate court stated that "[r]eformation may be had for a mutual mistake or for the mistake of one party which the other knew or suspected, but in either situation the purpose of the remedy is to make the written contract truly express the intention of the parties." ${ }^{79}$ In Shupe, the plaintiffs sued the defendants after access to the roadway from their garage and driveway was eliminated by construction of a fence. ${ }^{80}$ The lot owned by plaintiffs was part of a common housing development consisting of four lots. ${ }^{81}$ As part of the development plan, all four of the lots were to have access to the roadway. ${ }^{82}$ The access right to the

74. Id. $\S 151 \mathrm{cmt}$. a.

75. Id. $\S 152$. A party bears the risk of the mistake in the following instances:

(a) the risk is allocated to him by agreement of the parties, or (b) he is aware, at the time the contract is made, that he has only limited knowledge with respect to the facts to which the mistake relates but treats his limited knowledge as sufficient, or (c) the risk is allocated to him by the court on the ground that it is reasonable in the circumstances to do so. Id. $\S 154$.

76. FARNSWORTH, supra note $7, \S 9.3$.

77. See Eisenberg, supra note 51, at 1610-11 (defining mistranscriptions as a "special case of mechanical errors" where the appropriate relief is to amend the writing to reflect the actual bargain).

78. See CoRBIN, supra note $18, \S 614$ ("Reformation is not a proper remedy for the enforcement of terms to which the defendant never assented ...."). See also Kull, supra note 6, at 37 (stating that reformation is an innovative form of relief when mistake is present). Interestingly, the availability of "reformation" as a remedy in mutual mistake cases is expressly granted under section 3399 of the California Civil Code, even though reformation is not the typical remedy for mistake. See CAL. CIV. CODE $§ 3399$ (West 1997) (allowing revision of a contract in the case of mutual mistake).

79. Shupe v. Nelson, 62 Cal. Rptr. 352, 357 (Cal. Ct. App. 1967).

80. Id. at 355, n. 1 .

81. Id. at $355-56$.

82. See id. at 356 (stating that the "plan ... intended to reserve ... joint use and benefit for all four lots"). 
roadway for the plaintiffs' lot, however, was omitted from the deeds. The trial court found that the omission of the reservation of access rights was the result of a "mutual mistake," and ordered a reformation of all of the deeds to the four lots to include the omitted access rights. ${ }^{83}$ The appellate court agreed, stating that "[w]here the failure of the written contract to express the intention of the parties is due to the inadvertence of both of them, the mistake is mutual and the contract may be revised on the application of the party aggrieved." ${ }^{\prime 4}$ Yet, the facts indicate not a "mutual mistake" as to a "basic assumption," but a transcription error, something which the court acknowledges in stating that the defendant:

[F]ailed to properly instruct the title company at the time of the 1961 conveyances that [the plaintiffs'] lot was part of the same ownership and that the easements and right to use [the roadway] should also be included for the benefit of that lot. Mistake by a scrivener or draftsman in reducing the intent of the parties to writing is ground for reformation.

While the court inaccurately categorized the type of mistake, it focused on what was important - the intent of the parties. In Shupe, the parties intended to enter into an agreement that reserved access rights to the plaintiffs' property, but the agreement failed to reflect that intent. Cognitive and contextual purposive intent existed, but only with respect to the deeds as reformed. Conversely, the deeds as actually written should not have been enforced because both facets of intent to enter into the contract were lacking. Although inconsistent in its analysis of mistake, the court ordered the correct remedy, implementing what the parties intended.

In another case, Par 3, Inc. v. Livingston, ${ }^{86}$ the Nebraska Supreme Court mischaracterized the remedy in explaining the basis for nonenforcement. In Par 3, the defendant Livingston, president of a corporation called Castle Development, entered into a contract with the plaintiffs pursuant to which the corporation would purchase and plant trees for a proposed real estate and golf course development tentatively called Castle Brook. ${ }^{87}$ The contract was signed by representatives of the plaintiffs and by Livingston. ${ }^{88}$ The words "TITLE/CASTLEBROOK"

\footnotetext{
83. Id.

84. Id. at 357

85. Id. at 358 .

86. 686 N.W.2d 369 (Neb. 2004).

87. Id. at 371 .

88. Id.
} 
were typed below Livingston's signature, and above the word "TITLE," the defendant had written "Pres." 89 The Castle Brook project failed to develop and the plaintiffs filed suit against Livingston for breach of contract. ${ }^{90}$ In his answer, Livingston alleged that he was not personally liable on the contract because he was acting in his capacity as president of Castle Development. ${ }^{91}$ The district court agreed, and dismissed the plaintiffs' petitions. $^{92}$ The plaintiffs appealed, arguing that Livingston signed on behalf of an entity-Castle Brook-that was never incorporated, making him personally liable under Nebraska law. ${ }^{93}$ They further claimed that the court erred in using extrinsic and parol evidence to add to and vary the terms of a clear and unambiguous contract. ${ }^{94}$ Livingston argued that he intended to enter into the contract as president of Castle Development and that he was unaware at the time he signed the contract that the name of the entity on the document was incorrect. ${ }^{95}$

The district court concluded that Livingston intended to, and did, sign the contract as president of Castle Development, and not in his personal capacity. ${ }^{96}$ On appeal, the plaintiffs argued that the district court erred in reforming the contract. ${ }^{97}$ The Nebraska Supreme Court first noted that reformation may be had "when there has been either a mutual mistake or a unilateral mistake caused by fraud or inequitable conduct on the part of the party against whom reformation is sought." 98 The court then found that the lower court's conclusion that Livingston was not personally liable "was not based upon any alleged mistake in the contract, but was instead premised on the conclusion that none of the parties involved in the contract intended to incur personal liability." 99 The Nebraska Supreme Court thus concluded that "the district court did not reform the contract." 100 Yet, the finding that Livingston was not personally liable could be sustained only if there was a mistake in transcription and, at least, a consequent conceptual reformation of the contract to indicate that he signed the document as president of Castle

\footnotetext{
89. Id.

90. Id.

91. Id.

92. Id.

93. Id. at 372 .

94. Id. at 373 .

95. Id. at 372 .

96. Id.

97. $I d$. at 373

98. Id.

99. Id. In addition, plaintiff corporations' president "testified that he believed he was dealing with a corporation when he entered into the contract." Id. at 372.

100. Id. at 373 .
} 
Development and not Castle Brook. Furthermore, the court claimed that the evidence of Livingston's intent did not "add to and vary" the terms of the contract. ${ }^{101}$ On the contrary, the agreement stated in plain and unambiguous language that Livingston was signing the agreement on behalf of Castle Brook. The court denied the applicability of traditional contract law principles in order to address the important and more relevant issue of whether the parties intended for Livingston to incur personal liability under the agreement. The Par 3 court's conclusion is supported using my proposed intent analysis. Livingston lacked the cognitive intent to enter into the transaction because he did not understand that the contract was between himself personally (and not the corporation) and the plaintiffs. His contextual purposive intent in entering into the contract was to act as an agent for his company in conducting business - not to engage in the business transaction on his own behalf. Because the plaintiffs also believed that Livingston was acting on behalf of Castle Development, and not as an individual, the security of transactions objective was not undermined by dismissing the plaintiffs' claims.

The parties to a contract often are at a loss themselves as to which basic assumption defense is applicable, given the similarities of the defenses, and that the same factual circumstances give rise to different defenses. In one case, Nelson v. Cowles Ford, the plaintiff buyer sued the defendant car dealership after purchasing a used Ford Expedition with an altered odometer. ${ }^{102}$ The defendant car dealership raised the jumbled defense of "impossibility due to mutual mistake." 103 The court addressed the defendant's confusion regarding the defenses as follows:

Whether Cowles Ford intended to raise the distinct defense of mutual mistake is unclear, but in any event unimportant, because neither defense is applicable here. Mutual mistake only allows the injured party to void the contract.... Nelson [the plaintiff] is clearly the injured party because he paid for a vehicle with a market value much higher than he received. Impossibility under Virginia law exists only upon the occurrence of an event, the non-occurrence of which was the basic assumption upon which the contract was made .... Cowles Ford can identify no intervening occurrence in the case at bar.

101. Id. at 374 .

102. 77 Fed. App'x 637, 639 (4th Cir. 2003).

103. Id. at 643 .

104. Id. 
In some cases, the court itself will assist a party who relies upon an inapplicable defense. In Gutierrez v. Schultz, the plaintiff Gutierrez filed a negligence complaint for injuries after being struck by a truck driven by the defendant. ${ }^{105}$ The defendant Schultz filed a motion to dismiss, attaching a copy of a draft in the amount of $\$ 6000$ from Allstate Insurance, made payable to and endorsed by Gutierrez. ${ }^{106}$ The lower court granted the motion to dismiss and the plaintiff appealed, claiming, among other things, that "the court erred in not permitting parol evidence on the question of the issues of fraud, misrepresentation, and mutual mistake in connection with the draft." to dismiss, the plaintiff "sought to introduce evidence relating to the circumstances surrounding the acceptance and negotiation of the Allstate draft." 108 The court sustained defense counsel's motion to exclude the evidence based in part on the parol evidence rule. ${ }^{109}$ Gutierrez made an offer of proof and testified that an Allstate adjuster visited him while he was in the hospital. ${ }^{110}$ The adjuster told him that the company was concerned about his injuries and that Allstate "would take care of everything," including lost wages (approximately \$14,000) and medical expenses (approximately \$2500). ${ }^{111}$ The plaintiff claimed that the adjuster also told him that "if he needed money, Allstate would advance it to him." "112 Gutierrez claimed that two weeks before he received the check (which purported to be in exchange for a full and complete release), he had another conversation with the adjuster, and indicated that he would be amenable to a fair settlement, meaning lost wages, bills, and medical expenses. ${ }^{113}$ There was no agreement on a settlement amount, according to Gutierrez. ${ }^{114}$ Approximately two or three weeks after this conversation, Gutierrez received a check for $\$ 6000$ that contained on its face, in normal size print, the following language: "In payment of any and all claims including bodily injury arising from accident of 12-12-78 in Sterling, Illinois."

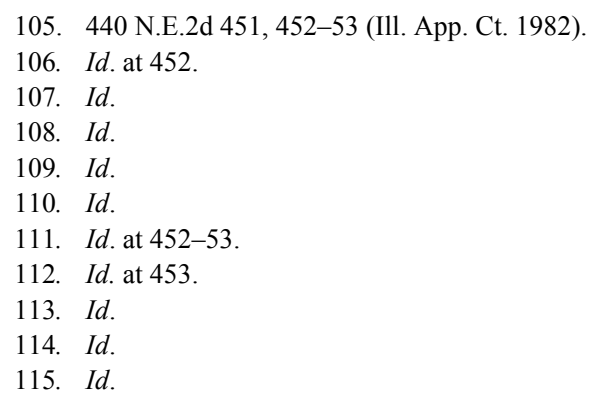


to be partial payment only. ${ }^{116} \mathrm{He}$ further testified that two or three weeks after he received the draft check, he received a release form from Allstate, which he threw away. ${ }^{117}$ After the offer of proof concluded, the lower court opined "that the check was a release of all claims, and that the plaintiff's endorsement of it estopped him from pursuing the negligence action."118 The lower court further stated its opinion that Allstate was not liable for fraud or misrepresentation, and concluded that there was no mutual mistake of fact. ${ }^{119}$

The Appellate Court for the Third District of Illinois reversed and remanded. Skirting the issues of fraud and mutual mistake, the court stated:

The threshold issue in the instant case is not whether the release should be set aside based upon fraud or mutual mistake, but whether there was a release at all. The plaintiff argues that the court erred in not considering his evidence concerning the circumstances leading up to and surrounding his endorsement of the check. Plaintiff's position is that his evidence indicated that it was not his intention, by endorsing and cashing the check, to release and fully settle his claim .... The insurer argues that the check on its face clearly and unambiguously evidences an intent to release and settle all claims arising from the accident. In so arguing, it concludes that the document is unequivocally a release and settlement of all claims and that any evidence to the contrary is impermissible. We disagree, and conclude that plaintiff's evidence ought to have been considered, since it was relevant to the issue of the intentions of the parties with respect to the check. $^{120}$

The court focused on contractual intent, but not as traditionally defined. While the plaintiff clearly had the volitional intent to accept the check (and thus, the settlement), contextual purposive intent and cognitive intent were lacking. The defendant sought to keep out the events that occurred prior to the cashing of the check under the parol evidence rule; however, those circumstances are relevant in examining the existence (or non-existence) of both cognitive and contextual purposive intent. The court noted that "the evidence of surrounding circumstances, which ought to have been considered on the issue of intentions, indicates that the insurance agent had represented that the company would take care of

\footnotetext{
116. Id.

117. Id.

118. Id

119. Id.

120. Id. at 454 .
} 
everything, including lost wages." ${ }^{\prime 21}$ In other words, the cashing of the draft in a vacuum does not provide an accurate picture of what the plaintiff intended when he so acted. The extrinsic evidence was needed to determine why the plaintiff cashed the check. Was it to settle the claim with Allstate, or to accept part payment of a forthcoming settlement?

In addition, the court indicated that cognitive intent was lacking when it stated the following:

In the instant case, the language on the check did not use the words release, discharge, settle or even payment in full. Furthermore, the language of release ... herein was in regular size print in the middle of the front of the check. We are not dealing in this case with a document entitled release and settlement, but rather with a document whose primary stated purpose and whose outward formal characteristics indicate that it is merely a check. Even assuming that the language used would be understood by the layman as a release and settlement, it would be inappropriate to assess that language divorced from the document as a whole, both its substantive and formal aspects. This document, except for the sentence with respect to what the payment was being made for, was in all other respects a check. We find it conceivable and reasonable, in light of the form of the document and the language used... that plaintiff herein felt that the check he received was merely payment towards his claim, and not full payment evidencing a final settlement and release of his claim. ${ }^{122}$

Thus, the court's objective is to determine the parties' multi-faceted intent. The $\$ 6000$ draft was filled out by a typewriter, with Gutierrez's name as claimant listed just below the name of Schultz as the insured. ${ }^{123}$ Just under Gutierrez's name, in the same size type, next to the words, "In payment of" were the words, "Any and all claims including bodily injury arising from accident of 12-12-78 in Sterling, Ill."124 As the dissent states, "I cannot believe that any reasonable person would interpret that statement to mean anything other than what it says; that the payment was intended to bar all personal injury claims of plaintiff arising out of the accident." 125 Yet, what the appellate court considered was not the intent of the "reasonable person," but Gutierrez's actual, subjective intent,

121. Id. at 455 .

122. Id.

123. Id. at 456 .

124. Id. (Barry, J., dissenting).

125. Id. 
taking into account the cognitive and contextual purposive facets of intent. ${ }^{126}$

\section{Unilateral Mistake}

In mutual mistake cases, both parties are operating under the same misperception as to material facts. ${ }^{127}$ In unilateral mistake cases, only one party has an erroneous perception as to the facts. ${ }^{128}$ In order to avoid a contract on the grounds of unilateral mistake, the adversely affected party must show the requirements necessary for mutual mistake. In addition, the adversely affected party must also show either that the effect of the mistake would make enforcement of the contract unconscionable or that the other party had reason to know of the mistake, or caused the mistake. ${ }^{129}$ If the doctrinal distinction between unilateral and mutual mistake is weak, the factual distinction is sometimes imperceptible. ${ }^{130}$ Not surprisingly, avoiding parties often seem confused about whether they should claim mutual or unilateral mistake, as the same facts often give rise to claims for both defenses. ${ }^{131}$

Courts generally have been reluctant to allow avoidance in cases where parties have sought relief on the grounds of unilateral mistake. ${ }^{132}$ Typically, successful cases have involved technical or computational errors. ${ }^{133}$ For example, in M.F. Kemper Construction Co. v. City of Los

126. See id. at 455 (majority opinion).

127. FARNSWORTH, supra note 7, at $\S 9.3$. A mutual mistake should be distinguished from a misunderstanding, where two parties attach different meanings to their language. $I d$. at $\S 9.2$.

128. Id. at $\$ 9.4$.

129. RESTATEMENT (SECOND) OF CONTRACTS § 153 (1981).

130. See Arthur Linton Corbin, Corbin on Contracts $\S 597$ (1960). See also Eric Rasmusen \& Ian Ayres, Mutual and Unilateral Mistake in Contract Law, 22 J. LEgAL STUD. 309, $312(1993)$

131. See Pub. Util. Dist. No. 1 v. Idacorp, Inc., 379 F.3d 641, 645 (9th Cir. 2004) (plaintiff utility company based complaint on theories of mutual mistake, unilateral mistake, duress and unconscionability); Am. Annuity Group, Inc. v. Guaranty Reassurance Corp. Liquidating Trust, 55 Fed. App'x 255, 256 (6th Cir. 2003) (defendant trust filed an amended counterclaim seeking reformation on the basis of mutual mistake, unilateral mistake, and fraud); Indep. Order of Foresters v. Donald, Lufkin \& Jenrette, Inc., 157 F.3d 933, 936-37 (2d Cir. 1998) (purchaser sued on the basis of both mutual and unilateral mistake); Lubrizol Corp. v. Exxon Corp., 929 F.2d 960, 962 (3d Cir. 1991) (appellant corporation claimed settlement agreement was the result of a "mutual mistake" or in the alternative, a "unilateral mistake"). See also ROBERT COOTER \& THOMAS Ulen, LAW AND ECONOMICS 258-59 (1988) (stating that courts often use the term "mutual mistake" in decisions not to enforce a promise and "unilateral mistake" in decisions to enforce a promise, thus emptying the terms of their original meanings)

132. See, e.g., M.F. Kemper Constr. Co. v. City of Los Angeles, 235 P.2d 7, 9-12 (Cal. 1951) ("Generally, relief is refused for error in judgment and allowed only for clerical or mathematical mistakes.").

133. Id. 
Angeles, the California Supreme Court allowed a construction company to cancel a bid it had submitted on public construction work. ${ }^{134}$ The company had unintentionally omitted a $\$ 301,769$ item in its bid, and did not discover its error until after the bids were opened. ${ }^{135}$ Pursuant to the city charter, the notice inviting bids provided that each bid must be submitted by a bond for an amount not less than ten percent of the bid amount as a guarantee that the bidder would enter into the contract if it were awarded to him. ${ }^{136}$ The charter further provided that after the bids were opened, they could not be withdrawn without the city's consent. ${ }^{137}$ All submitted bids would be "subject to acceptance by the city for a period of three months" even though the notice reserved to the city the right to reject any and all bids. ${ }^{138}$ The company immediately notified the city of its error and two days later, withdrew its bid. ${ }^{139}$ A few days later, the city passed a resolution accepting the erroneous bid. ${ }^{140}$ The company refused to enter into a contract, and the city awarded the contract to the next lowest bidder and demanded forfeiture of the company's bond. ${ }^{141}$ The California Supreme Court agreed with the lower court that the company's unilateral mistake permitted cancellation of the submitted bid and allowed the city to recover nothing. ${ }^{142}$

Yet, the California Supreme Court came to a different conclusion in another case involving a computational error made by a contractor in Drennan v. Star Paving Co. ${ }^{143}$ The defendant subcontractor had submitted a $\$ 7131.60$ bid to plaintiff general contractor for certain paving work. ${ }^{144}$ The plaintiff incorporated that bid in his own bid and "submitted it with the name of [the] defendant as the subcontractor for the paving." 145 The plaintiff was awarded the contract, and stopped by the defendant's office the following day. ${ }^{146}$ At that time, the defendant informed the plaintiff that he had made a mistake in the bid for the paving work and refused to do the paving work for less than $\$ 15,000 .^{147}$

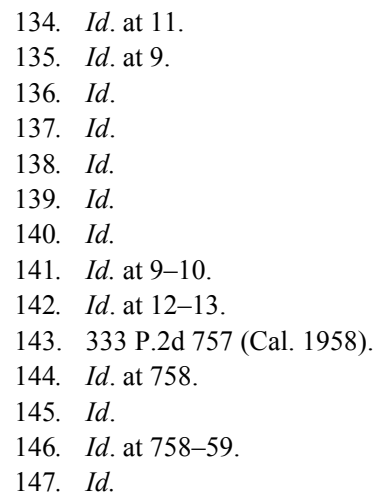


The plaintiff finally engaged another firm to do the work for about $\$ 11,000 .{ }^{148}$ The California Supreme Court affirmed the lower court decision in favor of the plaintiff and found that the doctrine of promissory estoppel could be used to make the offer binding. The California Supreme Court distinguished M.F. Kemper on the grounds that in that case there was no reasonable, detrimental reliance because "the bidder's mistake was known or should have been to the offeree, and the offeree could be placed in status quo."149

These two cases can be reconciled using a dynamic approach that adopts an expanded intent analysis. Both the contractor in M.F. Kemper and the subcontractor in Drennan lacked cognitive intent to enter into the contract. Both parties submitted bids based upon computational errors and both parties would not have entered into the contract if they had been made aware of their mistakes. Furthermore, both parties likely lacked contextual purposive intent. Their objective was presumably to make a profit on the services they would provide, which was likely undermined by their mistakes. Given the lack of both cognitive and contextual purposive intent, the societal interest in ensuring the security of transactions must be rather significant to compel enforcement. In M.F. Kemper, the non-avoiding party had not accepted the bid, and there was no detrimental reliance. ${ }^{150}$ Given the nature of the bidding process, the city was uninjured. The city had only to go to the next lowest bidder, as that bidder was compelled to keep its bid open for three months. ${ }^{151}$ Furthermore, there was no justifiable expectation interest as the contractor informed the city of his mistake only hours after the bids were opened, prior to acceptance, and with plenty of time for the city to find another contractor. ${ }^{152}$ In other words, the non-enforcement of the bid in M.F. Kemper was unlikely to deter future transactions.

On the other hand, the facts of Drennan provide a compelling rationale for enforcement. Unlike in M.F. Kemper, the non-mistaken party detrimentally relied on the mistake in committing to perform the general contract. ${ }^{153}$ To make matters worse, the mistaken party did not immediately notify the other party of his mistake and waited until the plaintiff paid him a visit. ${ }^{154}$ The failure to enforce the agreement in

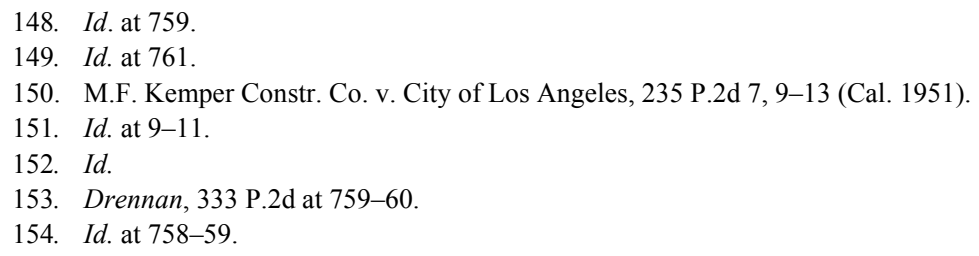


Drennan, given the existence of detrimental reliance and good faith on the part of the non-mistaken party (who spent several months trying to get other bids and who accepted the lowest of those bids), ${ }^{155}$ would likely deter similarly situated parties from future transactions, or more likely, burden the contracting process with onerous liability terms.

In another contractor case, the California Supreme Court allowed rescission of a contract on the grounds of unilateral mistake even though the contract was accepted prior to discovery of the mistake. In Elsinore Union Elementary School District v. Kastorff, the defendant, a building contractor, was sued by the plaintiff school district for damages after refusing to perform a winning construction bid. ${ }^{156}$ The defendant established that the bid resulted from a good faith mistake made under the pressure of the frenzied bidding process. ${ }^{157}$ The bid was accepted on August 12, and the defendant discovered the clerical error the next morning. ${ }^{158}$ That same morning, he notified the school district and asked to be released from the bid. ${ }^{159}$ On August 14, the defendant wrote a letter to the school district again explaining the error and asking to be released. ${ }^{160}$ On August 15, "the school district held a special meeting and voted not to grant Kastorff's request." district gave written notification of award of the contract and submitted a written contract for signature. ${ }^{162}$ The defendant refused and the school district sued. ${ }^{163}$ Using an expanded intent analysis, the court's decision can be explained given that the defendant did not have cognitive or contextual purposive intent to enter into an agreement based on the bid as submitted. Furthermore, the call for bids required all bidders to keep their bids open for a period of forty-five days after the date set for opening. ${ }^{164}$ While it is unclear whether the plaintiff had the option of accepting the next lowest bid, given the frenzied nature of the bidding process and the safeguards available to the party seeking bids, rescinding the contract caused minimal, if any, danger to the societal interest in the security of transactions.

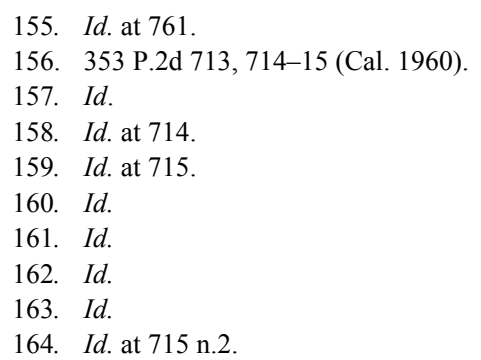


In a more recent case, Donovan v. RRL Corp., the California Supreme Court held in favor of a defendant automobile dealer who had made a typographical error by listing a used Jaguar for sale at a price that was approximately $\$ 12,000$ less than what he intended. ${ }^{165}$ The plaintiff test-drove the Jaguar, and then told defendant's salesperson, "Okay. We will take it at your price, \$26,000." " Then he was told that the advertisement was a mistake. ${ }^{167}$ The sales manager offered to pay for the plaintiff's fuel, time, and effort expended in traveling to the dealership, but the plaintiff refused. ${ }^{168}$ The sales manager then offered to sell the plaintiff the vehicle for $\$ 37,016$, approximately $\$ 900$ less than the intended sales price. ${ }^{169}$ The plaintiff refused and filed suit. ${ }^{170}$ The California Supreme Court ruled in favor of the defendant and reversed the appellate court's judgment on the grounds that the defendant had made a unilateral mistake in advertising the sale price of the Jaguar. ${ }^{171}$ In so doing, that court stated that to enforce the contract would be "unconscionable" because the mistake was an error amounting to thirtytwo percent of the intended price. ${ }^{172}$

In reality, it is unlikely that a $\$ 12,000$ mistake borne by a luxury car dealership would be "unconscionable," especially when that "loss" includes anticipated profit. In other words, the dealership had paid $\$ 35,000$ for the Jaguar. ${ }^{173}$ Thus, the "actual" loss was closer to $\$ 9000$. The court's decision may be given a more credible explanation using an expanded intent analysis. The defendant never intended to sell the vehicle at the advertised price. Thus, there was an absence of volitional, cognitive, and contextual purposive intent (assuming that the mistake was made in good faith and not a "bait-and-switch" maneuver). Furthermore, the plaintiff was notified of the error immediately after acceptance, and the defendant offered to pay for reliance damages. Thus, allowing the defendant to avoid the contract would not have a detrimental effect on the societal interest in the security of transactions. ${ }^{174}$

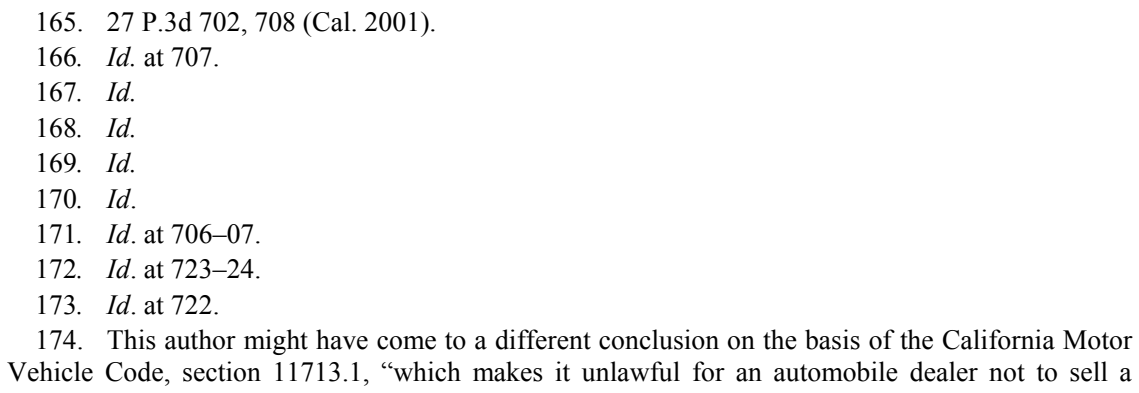

174. This author might have come to a different conclusion on the basis of the California Motor Vehicle Code, section 11713.1, "which makes it unlawful for an automobile dealer not to sell a 


\section{Misunderstanding}

Technically, misunderstandings are not defenses to contracts as they affect the very formation of a contract. In other words, if the parties lacked mutual assent, a contract was never formed in the first place, thus obviating the need for a defense. ${ }^{175}$ In practice, however, misunderstandings are used the same way that other contract defenses are used - to avoid enforcement of a contract. Furthermore, while the difference between misunderstanding and contract defenses is theoretically straightforward, the distinction that courts make between the two is often unclear in application. For example, in Krossa v. All Alaskan Seafoods, Inc. ${ }^{176}$ the Supreme Court of Alaska appears to have confused misunderstanding with mutual mistake. In that case, "John Krossa signed a contract with All Alaskan Seafoods to fish for crab in exchange for a percentage of the gross receipts."177 The Alaskan Supreme Court, in affirming the decision of the superior court, concluded that the contract between the parties was invalid because the parties "had different understandings of the term 'gross receipts.",178 In so concluding, that court stated that "if the term 'gross receipts' as used in the written agreement had no plain meaning and was instead ambiguous, we must conclude that no contract existed during that time."179 Although Krossa and All Alaskan Seafoods agreed that gross receipts should be defined as weight times price, they disagreed as to what the price should be. ${ }^{180}$ Krossa argued that because the contract contained an integration clause, the parol evidence rule barred introduction of extrinsic evidence in construing its meaning. ${ }^{181}$ The Alaskan Supreme Court disagreed, stating that the parol evidence rule does not apply "where a contract has been formed as a result of misrepresentation or mutual mistake." ${ }^{182}$ It further stated that: "[Where a party offered parol evidence] to show that the parties did not intend that the [contract] had the meaning the [other

motor vehicle at the advertised price while the vehicle remains unsold." Id. at 706.

175. See, e.g., Raffles v. Wichelhaus, 159 Eng. Rep. 375, 376 (1864). In Raffles, the parties entered into a contract for the sale and purchase of cotton scheduled to arrive on the ship Peerless. $I d$. at 375. Unknown to the parties, there were two ships named Peerless, and the parties were not referring to the same one. Id. See also Rasmusen \& Ayres, supra note 130, at 310 n.2 (noting that cases involving misunderstandings are "void" rather than "voidable").

176. 37 P.3d 411 (Alaska 2001).

177. Id. at 413 .

178. Id. at 416 .

179. Id.

180. Id.

181. Id. at 417 n.14.

182. Id. (quoting Philbin v. Matanuska-Susitna Borough, 991 P.2d 1263, 1270 (Alaska 1999)). 
party] ascribed to it, not to vary or contradict the terms of the written contract... this was a permissible use of extrinsic evidence to prove mutual mistake." $" 183$

While the court analyzed the issue as a misunderstanding, it referred to the basis for non-enforcement as "mutual mistake," stating that

although a party may avoid a contract based on mistake or misrepresentation regarding the contract's meaning, the party loses power to avoid the contract, "if, after he knows or has reason to know of the mistake or non-fraudulent misrepresentation ... he manifests to the other party his intention to affirm it . . .."184

If, however, the facts were as alleged, there was no "mutual mistake" because there was no shared mistaken basic assumption. Rather, there was a fundamental misunderstanding and therefore, no "meeting of the minds," and no contract at all. ${ }^{185}$ While the court erred with respect to what to label the basis for contract avoidance, it made clear that the relevant substantive issue was determining the parties' intent. ${ }^{186}$ If one party did not understand "gross receipts" to mean what the other party meant, then the contract could be avoided because the party did not have the cognitive intent to enter into the transaction that the other party contemplated. ${ }^{187}$

Not only do courts mislabel misunderstandings as mutual mistakes (and vice versa), courts often stumble on the interpretive issues associated with misunderstandings. In City of Everett v. Estate of Oddmund Sumstad, the buyers purchased at an auction a used safe with a locked compartment for fifty dollars. ${ }^{188}$ It was later discovered that the locked compartment contained $\$ 32,207$. $^{189}$ The Supreme Court of

\footnotetext{
183. Id. (citing Philbin, 991 P.2d at 1270).

184. Id. at 418 .

185. See supra note 175 and accompanying text. But $c f$. E. Allan FARNSWORTH, ALLEVIATING MistaKeS: REVERSAL AND FORGIVENESS FOR FLAWED PERCEPTIONS 14-15 (2004) (noting that the Peerless case was a "rare exception" and that "the mere fact that a party has a different perception of the other's understanding of the meaning of their language does not prevent a contract from arising.") "A court will almost invariably apply an objective standard and find that the meaning of the language accords with the understanding of one or the other of the parties." Id. at 14-15. Keith Rowley disagrees, stating that "Farnsworth overgeneralized in writing that a misunderstanding will not prevent contract formation. In fact, a mutual misunderstanding will prevent contract formation." Keith Rowley, To Err Is Human, 104 Mich. L. ReV. 1407, 1411 (2006) (reviewing E. Allen FARNSWORTH, AlleViating MistaKes: REVERSAl and Forgiveness For FlaWEd PERCEPTIONS (2004)).

186. See Krossa, 37 P.3d at 416 (describing the requirements of a valid contract).

187. Id.

188. 631 P.2d 366, 367 (Wash. 1981).

189. Id.
} 
Washington stated that Washington contract law was governed by an objective theory, which "lays stress on the outward manifestation of assent made by each party to the other. The subjective intention of the parties is irrelevant." ${ }^{900}$ The court further added that a party's intent must be imputed "corresponding to the reasonable meaning of a person's words and acts." "191 Yet, in distinguishing the case before it from West Coast Airlines, Inc. v. Miner's Aircraft \& Engine Service, Inc., ${ }^{192}$ the court seemed to confuse objective from subjective intent:

In West Coast Airlines, the aircraft engines were clearly not intended to be sold to Junk Traders. The inclusion of the engines in the sale of scrap metal was inadvertent and wholly unknown to both parties. Neither party was aware the sealed containers might hold anything other than scrap metal. Furthermore, West Coast Airlines retained the Federal documents that must be transferred to the purchaser upon the sale of an aircraft engine, a clear indication it did not intend to pass title to the engines. ${ }^{193}$

West Coast Airlines' "outward manifestation," as viewed by a reasonable person, indicates that it did, in fact, intend to sell the sealed containers containing the engines. The court differentiated the case before it by stating that the auctioneer had told the bidders that the safe had come from an estate, that the safe was locked, and that the contents of the safe had not been opened by the auctioneer. ${ }^{194}$ Yet, an acknowledgment by the auctioneer that the safe has not been opened is not the same as agreeing to sell for fifty dollars a safe containing over thirty thousand dollars.

The distinction between City of Everett v. Estate of Oddmund Sumstad and West Coast Airlines, Inc. v. Miner's Aircraft \& Engine Service, Inc. is not that in one case the party objectively manifested assent, and in the other it did not. In both cases, the seller objectively manifested assent to the sale, but the seller in West Coast Airlines lacked both the cognitive intent and contextual purposive intent to enter into the actual transaction. Not only was the seller in West Coast Airlines unaware that the sealed containers held aircraft engines, the seller did not even consider the possibility that it might contain something other than scrap material. ${ }^{195}$ Furthermore, the seller's contextual purposive intent in

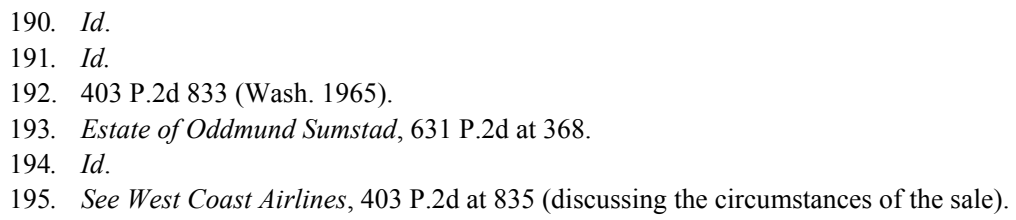


selling the scrap metal was both to earn money and to rid its premises of junk - not to get rid of airplane engines. By contrast, in Estate of Oddmund Sumstad, the seller (through the auctioneer) made explicit that he was assuming the risk that the safe might contain something more valuable than the auction price. In fact, it was precisely that unknown value that the buyers were bidding upon - not the market value of the safe or even the "unknown contents" of the safe. The sellers were not agreeing to sell a safe containing $\$ 30,000$ - they were agreeing to sell a safe that might contain something valuable within but just as likely might contain nothing. Both parties were aware of the possibility that the safe might contain something valuable and each was capitalizing on that possibility in the way that he thought best - the seller, in the hopes of getting a higher bid price, and the buyer, in the hopes of discovering a hidden treasure. While the seller did not know for certain that the safe contained money, he had expressly considered the possibility that it might. While the seller may have lacked actual knowledge of the safe's contents, he had the cognitive intent to enter into the transaction. The seller's contextual purposive intent in entering into the transaction was to auction the safe at the highest price possible, both to benefit financially as well as to disencumber himself from the item. Both of these objectives were met - the seller accepted the highest price and no longer had to store the safe. The contextual purposive intent of the seller was not defeated simply because he subsequently discovered that he might have received a higher price if he had known about the hidden money.

\section{B. Changed Circumstances}

Sometimes, a party seeks to avoid a contract as a result of a basic assumption error regarding the occurrence (or non-occurrence) of a condition subsequent to contract formation. In Taylor v. Caldwell (which has been recognized as the first case involving impossibility as a defense $^{196}$ ) the court established the rule that if the existence of a particular thing is necessary for a party's performance, then if such thing is destroyed, the party's performance under the contract is excused. ${ }^{197}$ In that case, the parties entered into a contract whereby Taylor was to use Caldwell's music hall for performances on four days, in return for payment of $£ 100$ per day. ${ }^{198}$ The music hall was accidentally destroyed

196. Gordley, supra note 6 , at 521 .

197. 122 Eng. Rep. 309, 314 (K.B. 1863) (cited in FARNSWORTH, supra note 7, § 9.5).

198. Id. 
by fire less than a week before the first performance. ${ }^{199}$ Taylor sued Caldwell for breach of contract, claiming damages incurred in preparation of the performances. ${ }^{200}$ The court decided that the continued existence of the music hall was an implied condition of the contract and, because the music hall was destroyed, Caldwell's performance was excused. ${ }^{201}$

The "implied condition" was a tacit assumption of the parties. The invalidity of the parties' tacit assumption reveals an absence of cognitive intent for both Taylor and Caldwell. Caldwell would not have agreed to rent out the music hall, and Taylor would not have agreed to rent it, if either had known the hall would be destroyed by fire. Furthermore, each party lacked contextual purposive intent to enter into the actual contract because the fire destroyed both parties' ability to perform. In other words, Caldwell never had the intent to enter into an agreement that required him to deliver possession of a non-existent structure, or one that needed to be entirely rebuilt. Similarly, Taylor lacked contextual purposive intent to enter into the contract because he wanted to rent the premises to stage music performances - something he could no longer do after the fire. He lacked contextual purposive intent because an event subsequent to the formation of the contract - the fire-destroyed his reason for renting the premises. The same circumstances - the fire and the subsequent destruction of the music hall-defeated the contractual intent of both parties. Yet, if Caldwell were to sue Taylor for breach of contract (assuming that there was no provision in the contract specifying the "condition" in which the music hall would be delivered), Taylor would not be able to use impossibility as a defense to the contract. Instead, he would have to resort to the doctrine of frustration of purpose.

The doctrine of frustration of purpose is nearly identical to the doctrine of impossibility and has been referred to as its "companion rule." 202 The difference is that with the frustration of purpose doctrine, "performance remains possible but the expected value of the performance to the party seeking to be excused has been destroyed" by the supervening event. ${ }^{203}$ The third changed circumstances doctrine,

199. Id.

200. Id.

201. Id.

202. Chase Precast Corp. v. John J. Paonessa Co., 566 N.E.2d 603, 605 (Mass. 1991).

203. Id. at 606 (citing Lloyd v. Murphy, 153 P.2d 47, 53 (Cal. 1944)). See also Posner \& Rosenfield, supra note 8, at 85 (“'Impossibility' is the rubric used when the carrying out of a promise is no longer 'physically possible,' and 'frustration of purpose' when performance of the promise is physically possible but the underlying purpose of the bargain is no longer attainable."). 
impracticability, has been referred to as a "catch-all" 204 for situations where performance is physically possible but would entail a much higher cost than originally expected. ${ }^{205}$ As Richard Posner and Andrew Rosenfield have noted, "[t]here is thus no functional distinction between impossibility and frustration cases on the one hand and impracticability cases on the other.",206

With all three doctrines, the central issue concerns the allocation of risk, independent of fault, of the event giving rise to the claim of impossibility, frustration of purpose, ${ }^{207}$ or impracticability. The allocation of risk, however, is not always readily determinable. ${ }^{208}$ Posner and Rosenfield have argued that a party should bear the risk if he or she is in a better position than the other party to foresee the risk, insure against it, or prevent the risk from occurring. ${ }^{209}$ James Gordley, on the other hand, observes that while foreseeability is helpful to explain the result in some contexts, it is not so helpful in others, such as war, where neither party could have foreseen the intervening event. ${ }^{210}$ In those situations, Gordley observes, the results seem related to the degree to which a party could have controlled the event that made performance impossible. ${ }^{211}$ Thus, control matters because the party in control could have decreased the risk by taking reasonable precautions. ${ }^{212}$

The solution promoted under the Uniform Commercial $\operatorname{Code}^{213}$ and the Restatement (Second) of Contracts ${ }^{214}$ is that performance may be excused if it was premised upon a "basic assumption" that was false. U.C.C. section 2-615 states:

204. Posner \& Rosenfield, supra note 8 , at 86

205. Id. The doctrine of commercial impracticability is believed to have first appeared in Mineral Park Land Co. v. Howard, 156 P. 458 (Cal. 1916). See Sheldon W. Halpern, Application of the Doctrine of Commercial Impracticability: Searching for "the Wisdom of Solomon," 135 U. PA. L. REV. 1123, 1132 (1987).

206. Posner \& Rosenfield, supra note 8 , at 86 . In his article, Kull similarly uses the word "frustration" to encompass all the doctrines of frustration of purpose, impracticability, and impossibility. See Kull, supra note 6, at 1 n.1.

207. Posner \& Rosenfield, supra note 8, at 86. See also Gordley, supra note 6, at 524.

208. Posner \& Rosenfield, supra note 8 , at 86 .

209. Id. at 90. See also Gordley, supra note 6, at 524.

But see Kull, supra note 6, at 47 ("Superior risk-bearing capacity as determined after the fact by judges is therefore a default term that conveys no usable information to the parties; and an uninformative default term cannot be the source of any economies from superior risk spreading.").

210. Gordley, supra note 6 , at 524

211. Id.

212. Id.

213. U.C.C. $§ 2-615$ (1998).

214. RESTATEMENT (SECOND) OF CONTRACTS § 261 (1981). 
Except so far as a seller may have assumed a greater obligation ... (a) Delay in delivery or non-delivery in whole or in part by a seller . . . is not a breach of his duty under a contract for sale if performance as agreed has been made impracticable by the occurrence of a contingency the non-occurrence of which was a basic assumption on which the contract was made ....,215

The doctrine of commercial impracticability, unlike the common law doctrine of impossibility, expressly recognizes that fault should be relevant to risk allocation and that in certain cases justice requires a departure from the general rule that a promisor bears the risk of increased difficulty of performance. ${ }^{216}$ The avoiding party must meet four requirements. First, the avoiding party must show that the occurrence of the event made " "performance as agreed... impracticable.", 17 If the agreement gives the party seeking avoidance a choice between alternative ways of performing, the impracticability of performing one of these alternatives does not excuse performance if another alternative remains open. ${ }^{218}$ Second, the nonoccurrence of the condition must have been a "'basic assumption on which the contract was made.",219 As Gordley notes, "[t]o ask on what basic assumptions a contract was based is not much different than asking ... on what implied conditions it was made." 220 Whether the nonoccurrence was in fact a basic contract assumption is thus a question of foreseeability. ${ }^{221}$ Market fluctuations, for example, are usually foreseeable. ${ }^{222}$ Third, the avoiding party must not be at fault by, for example, acting negligently. ${ }^{223}$ Finally, the party seeking avoidance must not have contractually assumed a greater obligation than that imposed by law. ${ }^{24}$

215. Although section 2-615 expressly applies to commercial sellers, it has been interpreted by some courts to include buyers as well. See, e.g., Lawrance v. Elmore Bean Warehouse, Inc., 702 P.2d 930, 932 (Idaho 1985) (stating that the provisions of U.C.C. section 2-615 are "applicable to buyers as long as there is compliance with the statutory requirements").

216. FARNSWORTH, supra note 7, § 9.6.

217. Id.

218. Id.

219. Id.

220. Gordley, supra note 6, at 525 .

221. Lawrance v. Elmore Bean Warehouse, Inc., 702 P.2d 930, 932 (Idaho 1985).

222. The accompanying comment explains that "[i]ncreased cost alone does not excuse performance unless the rise in cost is due to some unforeseen contingency which alters the essential nature of the performance. Neither is a rise or a collapse in the market in itself a justification, for that is exactly the type of business risk which business contracts made at fixed prices are intended to cover." U.C.C. § 2-615 cmt. 4 (1998).

223. FARNSWORTH, supra note $7, \S 9.6$.

224. Id. 
As several scholars have noted, the focus on "foreseeability" misses the point and unnecessarily restricts the impracticability doctrine. ${ }^{225}$ Whether an event is foreseeable does not necessarily correlate with what the parties intended, and silence does not necessarily mean that the party seeking avoidance intended to assume the risk. ${ }^{226}$ I submit that all three changed circumstances doctrines provide for excuse in the absence of contextual purposive intent. For example, in Taylor v. Caldwell, Caldwell entered into the agreement assuming the continued existence of the music hall. He lacked cognitive intent because he failed to consider the possibility of a fire, and he lacked contextual purposive intent to enter into the contract as the circumstances turned out to be.

Contextual purposive intent requires judicial consideration of the circumstances of the transaction both before and after the time of contract formation. A consideration of "context" requires taking into account trade norms unless a contrary subjective understanding can be credibly proven. In Taylor v. Caldwell, the court decided in Caldwell's favor. If, however, the case were to arise today, given the prevalence and customary nature of landowner's insuring against fire damage, the result might be different. Caldwell would likely have considered the possibility of fire (thus, cognitive intent would exist). In addition, it has become customary, at least in the United States, for landowners to carry fire insurance on their properties. The existence of an industry norm partially determines context. The courts have established such a norm in contractor cases. Where a contractor has been hired to construct a structure, the destruction of that structure by fire or otherwise will not excuse the contractor's performance. If, however, the contractor has been hired to build an addition to an existing structure, destruction of that existing structure will excuse the contractor's performance. The underlying rationale for distinguishing these two types of situations hinges upon the fact that in the latter situation, the landowner is in a better position than the contractor to insure against destruction of the structure (whereas the contractor is in a better position to prevent damage and insure against destruction of a new structure). The Uniform

225. John H. Stroh, The Failure of the Doctrine of Impracticability, 5 CORP. L. REV. 195, 216 (1982) (noting that the difficulty with foreseeability is that "it ignores the 'how' and 'why' businessmen contract"); George Wallach, The Excuse Defense in the Law of Contracts: Judicial Frustration of the U.C.C. Attempt to Liberalize the Law of Commercial Impracticability, 55 NOTRE DAME L. REV. 203, 204-07 (1979).

226. Stephen J. Sirianni, The Developing Law of Contractual Impracticability and Impossibility: Part I, 14 UCC L.J. 30, 65 (1981) (stating that to foresee a risk is not the same as allocating that risk); Wallach, supra note 225 at 214-15 (noting that parties often are unable to agree on an allocation even where a contingency is foreseeable). 
Commercial Code also considers insurance in the context of risk of loss, although it does so rather coyly. ${ }^{227}$

\section{EXPECTED ARgUMENTS AgAINST PROPOSED DYNAMIC APPROACH/EXPANDED INTENT ANALYSIS}

\section{A. Argument \#1: Subjective Intent Is Impossible to Determine}

Some may object that discerning subjective intent is extremely difficult, if not impossible. ${ }^{228}$ This objection ignores that the issue of subjective intent already exists in contract disputes, both in defenses ${ }^{229}$ and interpretation issues. ${ }^{230}$ In fact, focusing on subjective rather than objective intent is more consistent with the underlying "will theory" of contract law. Furthermore, it reflects the position adopted by the Uniform Commercial Code. ${ }^{231}$ The "real world" issue will be one of credibility. In most cases, the courts will assume that the parties intended what reasonable contracting parties would have intended. ${ }^{232}$ If,

227. U.C.C. § 2-510 (1998) (putting risk of loss on the breaching party to the extent that the nonbreaching party's insurance fails to cover the loss).

228. James Gordley notes that "nearly all modern jurists agree that an error in motive does not warrant relief." See Gordley, supra note 36, at 435.

229. See, e.g., Parev Prods. Co. v. I. Rokeach \& Sons, 124 F.2d 147, 149 n.2 (2d Cir. 1941) (declaring that the court reached the outcome the parties would have intended if they had "foreseen the present contingency").

230. Halpern, supra note 205, at 1127 (noting that the fictions used by the court in impossibility cases are "essentially the same tools that are applied to other questions of contract interpretation and enforcement"). Edward Imwinkelried suggests that "interpretative intention" or the "intention that a person probably would have formed if he or she had foreseen the circumstances that came to pass," should be employed by judges in interpreting (outdated) legislation. Edward J. Imwinkelried, $A$ More Modest Proposal than a Common Law for the Age of Statutes: Greater Reliance in Statutory Interpretation on the Concept of Interpretative Intention, 68 ALB. L. REV. 949, 953 (2005). But see Rasmusen \& Ayres, supra note 130, at 309 ("Reforming or voiding contracts ... goes beyond the gap-filling function in which courts customarily engage; it is an almost paternalistic change in the contract's express terms. Hence, contract law must be very careful how it treats 'mistake."').

231. Many commentators view the Code's adoption of the shared "basic assumption" test as a departure from the fiction of objective intent to an analysis that takes into account subjective intent. For instance, Halpern states that the Code's shift would result in the concept of "foreseeability" giving "way to a new behavioral analysis with the inquiry focused on what the parties actually contemplated." Halpern, supra note 205, at 1147. Yet, he argues that the Code's "subjective search for actual intent has not in fact displaced the centrality of objective foreseeability" by courts. Id. at 1148. Halpern, however, states that "if we dislike the concept of foreseeability, we might better ask whether intent, subjectively or objectively determined, is an appropriate or even relevant consideration in allocating the risks of seriously disruptive events and whether there are any workable alternatives." Id. at 1154. This Article, on the other hand, suggests that intent is highly relevant; it must, however, be balanced against policy considerations.

232. See Grover C. Grismore, Principles of the LaW of Contracts 253 (John Edward Murray, Jr., rev. ed. 1965) ("What we are really doing is imposing an obligation which the party obligated, were he a reasonable man, probably would have been willing to assume, had the question 
however, there is credible evidence that demonstrates a contrary intent, that finding of actual intent should trump the hypothetical, objective intent. The evidentiary bar for the avoiding party is noteworthy given the requirement of "good faith," for the avoiding party must convince the judge that she is telling the truth when she claims that although she acted unreasonably, she acted honestly with respect to her intention in entering into the agreement.

\section{B. Argument \#2: Courts Should Not Make Policy}

Another concern likely to be raised is legislating from the bench. This concern is most salient in connection with the consideration of contextual purposive intent, which considers policy issues such as economic efficiency and fairness. Yet, the basic assumption defenses currently existing already consider policy. ${ }^{233}$ In fact, to the extent that a legislative body has adopted the UCC, a refusal to incorporate these policy objectives undermines legislative authority and is itself judicial legislation. ${ }^{234}$ This Article does not promote any new policies in connection with existing basic assumption defenses. What it does advocate is the separation of the two central concerns addressed by existing basic assumption defenses. In each defense, there is an intent inquiry regarding the parties' contractual purpose. ${ }^{235}$ Currently, mistake defenses limit that inquiry to the facts at the time of contract formation, while changed circumstances doctrines consider facts arising after contract formation. ${ }^{236}$ More importantly, however, formalistic constraints subvert the underlying purpose of contract law. We infer intent from actions, and context gives meaning to actions. To require performance where circumstances have undermined contextual purposive intent is to ignore the very reason why we enforce contracts. ${ }^{237}$ To illustrate this on a very basic level, imagine that a parent makes a promise to her child that they will go swimming later in the day. The child falls asleep in the car and does not awaken until several hours later

presented itself when the contract was made.”).

233. See Eisenberg, supra note 2, at 747, 757 (discussing fairness and efficiency as the basis for the bargain theory and principles of unconscionability).

234. George Wallach has argued that courts have adhered to the common law standards for excuse and have ignored the UCC drafters' intent to liberalize those standards, making the successful use of commercial impracticability as a defense difficult, if not impossible. See Wallach, supra note 225 , at 203, 218.

235. See supra Part III.

236. Id.

237. See Eisenberg, supra note 51, at 1624 (stating that "a literalist approach undermines the purpose of contract law"). 
when it is dinnertime. A very young or very manipulative child will insist that the parent adhere to her promise. A more mature or less manipulative child will understand that the circumstances warrant a change in plans, and that there will be no swimming that day. That child may feel disappointed, but he will understand the reason that the promise must be broken. The moral obligation to keep a promise does not always override every other obligation, moral or otherwise, and not every broken promise is immoral. ${ }^{238}$ Like the mature child, a more developed legal system would recognize that, sometimes, context changes the meaning of words.

\section{Argument \#3: A Dynamic Approach Is Unfair}

Some may ask, what about the other party, the non-avoiding party? Should his interests not be protected? The answer is that the other party's interests are considered at each step of the proposed intent analysis. Volitional intent takes into account socially unacceptable behavior on the part of the other party, such as the making of threats or the use of intimidation, which does not so much protect the non-avoiding party's interest as discern whether it is worth protecting at all. Cognitive intent analysis requires asking whether the parties discussed or considered the facts giving rise to the request for avoidance. Contextual purposive intent considers trade norms and fairness issues, such as the existence or availability of insurance. ${ }^{239}$ Finally, even where one or more facets of intent may be lacking, the contract may yet be enforced if the societal interest in the security of transactions is great enough, such as where both parties have fully performed, where there is reliance, ${ }^{240}$ or where the market is inherently speculative. ${ }^{241}$

238. Mel Eisenberg discusses this point with respect to mistakes: "Some types of mistake provide a moral justification for not keeping a promise. Correspondingly, a promisee may act badly if she insists on full performance even after she has been made aware of such a mistake." Eisenberg, supra note 51, at 1579 . He further states that in some cases, two moral norms may conflict:

[f]or example, the moral norm "don't lie" is not inconsistent with the moral norm "venerate human life," even though under certain circumstances venerating human life might require lying - as in lying to an assassin about his victim's whereabouts. It does not lessen our commitment to truth-telling that we believe it is sometimes morally permissible not to tell the truth.

Id. at 1581

239. See Anthony T. Kronman, Mistake, Disclosure, Information, and the Law of Contracts, $7 \mathrm{~J}$. LEGAL STUD. 1, 4 (1978) (noting that insurance is often the only effective means of risk reduction); Posner \& Rosenfield, supra note 8, at 91.

240. The reliance would also have to be in good faith.

241. For example, because of the difficulty, even impossibility, of establishing authenticity or establishing pricing for art, invalidating contracts where there was a failure of cognitive intent may 
An expanded intent analysis streamlines the current regime of contract defenses, which is generally agreed to be inexact at best, and incoherent at worst. It erases the artificial distinctions inherent in the doctrinal categories (such as the timing of the discovery of the excusing condition) to focus on what courts tend to focus on anyway-contractual intent. It is flexible enough to accommodate evolving business and social norms. In particular, the Internet has provided a useful new medium by which to conduct transactions while its very widespread availability and accessibility create more opportunities for basic assumption errors.

Let us return to the hypothetical Internet homebuyer presented at the beginning of this Article. Our homebuyer purchased her home after viewing several attractive pictures that accurately reflected the home's condition. They did not, however, reveal something of great importance to the homebuyer. She lacked the cognitive intent to enter into the transaction because she did not know about the noise from the nearby road. Her contextual purposive intent in entering into the transaction was to purchase a home that provided peace and tranquility. Under my proposed intent analysis, she should therefore be permitted to avoid the agreement provided that it is not offset by the societal interest in the security of transaction. If, for example, she had not discovered the noisy road until she had moved into the house, she should not be allowed to avoid the agreement. This expanded intent analysis thus reflects something more than legal obligations - it reflects the way people actually conduct business. ${ }^{242}$ Merchants are not required to refund conforming purchases to unhappy customers, ${ }^{243}$ but many do anyway and claim "satisfaction or your money back, no questions asked." Permitting avoidance would also encourage fuller disclosure by Internet sellers. Existing law generally does not impose a duty to disclose; yet imposing upon the purchaser the same standards of investigation as those existing prior to the advent of the Internet diminishes many of the advantages of conducting business online, such as reduced travel expenses. Allowing the purchaser to avoid a contract where there is a lack of cognitive intent would prompt Internet sellers to provide a more accurate description of their wares. If we accept that the Internet confers a benefit on the

cause "a chain of contracts [to] fall like dominos as far back as the available evidence will go." See Gordley, supra note 36 , at 455 .

242. This hypothetical is based on an actual situation where the buyer was able to get out of the purchase. See Tim Neville, Buying a Second Home Without a First Look, N.Y. TimES, Aug. 5, 2005, at F6. See also Elizabeth Rhodes, Buyer's New Buddy, SeAtTle Times, Feb. 5, 2006, at G1.

243. The U.C.C. requires merchants to provide a remedy for nonconforming merchandise unless expressly and conspicuously disclaimed. See U.C.C. $\S \S 2-313$ to -316 (1998). 
economy and society - because it promotes the contract law objective of economic efficiency by providing an accessible marketplace where more private parties can allocate resources to a higher valued use $^{244}$-we should also acknowledge and accommodate the paradigmatic shift it has created in the way contracts are formed.

\section{CONCLUSION}

Contract law has historically acknowledged the importance of the intent of the parties in contract interpretation and enforcement. Yet, the meaning of "intent" has been left unexamined. Basic assumption defenses exemplify the dynamic nature of neoclassical contract law. Dynamic contract law first effectuates the objectives of the contracting parties and then considers any policy constraints on those objectives. ${ }^{245}$ In order for contract law to be truly dynamic, however, both parts of the analysis must be dynamic and contextualized. An evaluation of policy considerations is, by its nature, dynamic and contextualized as it takes into account societal needs at the time and place of dispute resolution. Traditionally, consideration of contractual intent, although somewhat contextual, is seldom dynamic. Classical contract law's vision of intent is static (as opposed to dynamic) because it only considers intent as it exists at the time of contract formation. A failure to examine contractual intent in light of events subsequent to contract formation often undermines the purpose of the contract. ${ }^{246}$

Furthermore, contract law's treatment of intent is only partly contextual because of the continuing influence of the "objective" standard of reasonableness. While classical contract law theoretically enforced contracts because the individual had assumed contractual liability, ${ }^{247}$ it did so by viewing the individual's actions from the standpoint of a reasonable person ${ }^{248}$ rather than by considering the

244. Online real estate companies, for example, provide sellers with alternatives other than having to pay the standard real estate agent commission of 6\%. Rhodes, supra note 242. Auction sites, such as eBay, exemplify the execution of value optimization by private parties.

245. See generally Eisenberg, supra note 23.

246. See supra Part III

247. See, e.g., Feinman, supra note 23, at 1286.

248. See Eisenberg, supra note 23, at 1749 (discussing the rigidity of classical contract law). DiMatteo has traced the roots of the "reasonable person" to a "Greek philosophical tradition grafted on to Roman law by moral philosophers." DiMatteo, supra note 32, at 305 . He further notes that the objectivity of contracts was historically measured by religious morality:

In the Middle Ages the convergence of canon and secular law was embodied in the rediscovery of Justinian's Codex, Novellae, Institutiones, and Digestae. This was the genesis of the idea of the existence of an autonomous device to judge private exchanges 
individual's subjective intent. ${ }^{249}$ Classical contract law's adoption of the objective theory of interpretation considered the actual, unexpressed intent of the parties as irrelevant. ${ }^{250}$ Instead, the courts considered the overt acts of the parties rather than their subjective beliefs or motivations. ${ }^{251}$ The modern approach, adopted by the Second Restatement, reflects a mix of both objective and subjective elements. ${ }^{252}$ Under that view, language is interpreted in accordance with its generally

and relationships .... The reasonable person can be seen as an external, autonomous source, much in the order of this tradition.... The equating of breach of promise to dishonesty in business "combined to give to contracts a measure of religious blessedness and to breaches of contract a mark of sinful or unethical aberration." The morality of promise was the autonomous measure to which the contract breaker was to be held .... The genesis of the reasonable person can be seen in law's religious ancestors .... One can see the reasonable person as the embodiment of Aquinas' notion of human reason.

Id. at 306-07 (citing SiR DAVID Hughes PARRY, THE SANCTITY OF CONTRACTS IN ENGLISH LAw 6 (1959)).

249. Eisenberg, supra note 23, at 1756-58. This seeming inconsistency is reflected in classical contract law's formalistic static and binary nature. Id. at 1749. Larry A. DiMatteo notes that

[a]t first, the will theorists viewed the reasonable person standard as merely providing evidence of the subjective understanding of the parties .... In the process of formalizing and generalizing the system of contract law, the legal rules came to bear a more and more tenuous relationship to the actual intent of the parties. What once could be defended and justified as simply a more efficacious way of carrying out the parties' intentions came eventually to be perceived as a system that subordinated and overruled the parties' will.

DiMatteo, supra note 32, at 297.

250. See FUller \& EISENBERG, supra note 1, at 383-84 ("Classical contract law adopted a theory of interpretation that was purely, or almost purely, objective.").

251. Id. The court in Woburn National Bank v. Woods, espoused the objective theory of contract when it stated:

A contract involves what is called a meeting of the minds of the parties. But this does not mean that they must have arrived at a common mental state touching the manner in hand. The standard by which their conduct is judged and their rights are limited is not internal but external. In the absence of fraud or incapacity, the question is: What did the party say and do? "The making of a contract does not depend upon the state of the parties' minds; it depends upon their overt acts."

89 A. 491, 492 (N.H. 1914).

252. The Restatement provides as follows:

(1) Where the parties have attached the same meaning to a promise or agreement or a term thereof, it is interpreted in accordance with that meaning.

(2) Where the parties have attached different meanings to a promise or agreement or a term thereof, it is interpreted in accordance with the meaning attached by one of them if at the time the agreement was made

(a) that party did not know of any different meaning attached by the other, and the other knew the meaning attached by the first party; or

(b) that party had no reason to know of any different meaning attached by the other, and the other had reason to know the meaning attached by the first party.

(3) Except as stated in this Section, neither party is bound by the meaning attached by the other, even though the result may be a failure of mutual assent.

RESTATEMENT (SECOND) OF CONTRACTS $§ 201$ (1981). 
prevailing meaning unless a different intention is shown. ${ }^{253}$ Thus, classical contract law's influence remains today. The objective theory of contracts replaces the underlying purposes of contract lawpromulgating the intent of the parties - with a normative function; the reasonable person is himself a norm.

The primary objective of contract law is not, however, to standardize contracting behavior. Perhaps the single most acknowledged justification for contract enforcement is that contracting promotes individual autonomy or the "will of the parties." ${ }^{254}$ Yet, the parties to a contract are not always "reasonable," or at least not reasonable as such a term may be understood by a decisionmaker with a different background and experiences. ${ }^{255}$ People, even where they are reasonable, are not always reasonable in the same way. Parties often do not always share the same assumptions, experience, cultural or social values, bargaining power or access to information, either with each other or with the decisionmaker or hypothetical reasonable person. Thus, even if we were to accept dynamic contract law's view of contractual intent as purely subjective, we must still resolve the issue of how we should analyze such intent.

In this paper, I have proposed one possibility for evaluating intent and applied this expanded intent framework in the context of basic assumption defenses. A dynamic approach to mistaken basic assumption-type situations (which would replace existing defenses)

253. Id. The Second Restatement expressly acknowledges that

there are substantial differences between English and American usages and between usages in different parts of the United States. Differences of usages also exist in various localities and in different social, economic, religious and ethnic groups. All these usages change over time, and persons engaged in transactions with each other often develop temporary usages peculiar to themselves. Moreover, most words are commonly used in more than one sense.

Id. $\S 201 \mathrm{cmt}$. a.

254. Friedrich Kessler, Introduction: Contract as a Principle of Order, in FRIEDRICH KeSSLER ET AL., CONTRACTS (3d ed. 1986), reprinted in A CONTRACTS ANTHOLOGY 32, 34 (Peter Linzer ed., $2 d$ ed. 1995); Roscoe Pound, An Introduction to the Philosophy of Law 149 (1954). See generally, FRIED, supra note 19.

255. See Blake Morant, Law, Literature, and Contract: An Essay in Realism, 4 Mich. J. RACE \& L. 1, 7-8. As Blake Morant notes, "[I]n many controversies involving principles of contract, factors of race, ethnicity or gender can play a tangential, if not pivotal, role in the formation and adjudication of many binding obligations." Id. He further notes,

[t] he contextual circumstances presented by notable contract decisions [such as Williams v. Walker Thomas Furniture Co. and Richmond v. J.A. Croson Co.] compel a readjustment of contract pedagogy and demand a more probative analysis of bargaining relationships. Thus, factors of racial or gender bias command attention, particularly when they can impact the formation or judicial interpretation of agreements. 
would apply expanded intent analysis first, and then consider whether the societal interest in the security of transactions compels enforcement notwithstanding the absence of one or more facets of intent. By eliminating the doctrinal categories, a dynamic approach streamlines analysis of cases where what the parties bargained for is very different from what they received. Dynamic contract law strives to effectuate the underlying objectives of contract law, rather than merely adhering to the rules that implement those objectives. Finally, a dynamic approach is adaptive and accommodates changes in contracting culture brought about by technological advancements and globalization. ${ }^{256}$

256. See generally Kim, supra note 23 . 